Ministerstwo Nauki

i Szkolnictwa Wyższego

Digitalizacja archiwalnych numerów czasopisma naukowego Analecta Cracoviensia 1-24 (1969-1992)

i ich publikacja w otwartym dostępie - zadanie finansowane w ramach umowy 672/P-DUN/2017 ze środków

Ministra Nauki i Szkolnictwa Wyższego przeznaczonych na działalność upowszechniającą naukę

KS. BOLESŁAW PRZYBYSZEWSKI

\title{
JADWIGA I WILHELM
}

W S T E P

Rola Wilhelma, księcia austriackiego, w życiu Jadwigi Andegawenki już od wieku XIV, a szczególnie w wieku następnym, była dręczącą w opinii światowej zagadką, od której rozwiązania wiele zależało i zależy przy próbach określenia jej osobowości. Pytano, czy Jadwiga była rzeczywiście, jak pisały XV-wieczne źródła (kroniki, roczniki), płochą dziewczyną, która po zaręczynach z władcą Litwy, pod wpływem nieopanowanego uczucia utrzymywała kontakty $z$ dawnym narzeczonym, co więcej poważyła się prawie tuż przed przyjazdem oczekiwanego kandydata na męża uprawomocnić dziecinne śluby zawarte $\mathrm{z}$ rakuskim chłopcem, by potem pędzić życie $\mathrm{w}$ rozterce sumienia jako konkubina na tronie polskiego króla. Czy znoszenie złośliwych ataków na jej małżeństwo z Jagiełłą ze strony obozu austriacko-krzyżackiego było pewną formą pokuty za lekkomyślny krok nieopatrznie w przeszłości uczyniony, czy też specyficznym rodzajem moralnego męczeństwa zadanego jej niewinnemu sercu?

Historykom wydarzeń politycznych, związanych z małżeństwem Jadwigi, cały spór o prawa Wilhelma do królowej Polski wydaje się „niesmaczny i całkowicie zbędny" ${ }^{1}$. Wypadki bowiem ówczesne biegły wytyczonymi przez zabiegi polityczne torami bez względu na stan serca Jadwigi. Przyjazd Wilhelma do Krakowa w sierpniu 1385 był mało znaczącym epizodem w stosunku do wielkiego dzieła unii polsko-litewskiej. Jednak dla biografa Jadwigi nie jest rzeczą obojętną, czy Andegawenka była postacią tragiczną na polskim tronie, zalęknioną małżonką Władysława Jagiełły, czy też królową, która pojawiwszy się jako młoda dziew-

1 J. Caro, Geschichte Polens, Gotha 1863, t. II, 505-506;S. M. Kuczyński, Rozbiór krytyczny r. 1385 „Dziejów polskich” Jana Długosza, w: Studia Źródłoznawcze, Commentationes III, Poznań 1958 (Kuczyński), 251-252. 
czynka na polskiej widowni dziejowej od początku była świadoma swej drogi życiowej, którą jej wypadło iść i umiała z godną podziwu roztropnością zdążać do zamierzonego celu.

Dzieje Jadwigi i Wilhelma były często omawiane w literaturze historycznej ${ }^{2}$, której przedstawiciele szczęśliwie coraz więcej wyzwalali się od wpływu balamutnych relacji Jana Długosza, zachowując jednakże cenne okruchy prawdy, lśniące na kartach dzieł wielkiego dziejopisa polskiego średniowiecza. Hagiografów zaś i popularyzatorów pociągał romantyczny wątek miłości dwojga dzieci, które okrutny los oddzielił od siebie. Z tym się łączyło współczucie dla Jadwigi przeznaczonej dla barbarzyńskiego, dużo od niej starszego księcia Litwy, a zarazem podziw dla ofiary serca, jaką królowa złożyła przed Ukrzyżowanym, w celu pozyskania dla chrześcijaństwa ostatniego narodu pogańskiego w Europie. Przystępując obecnie do opracowania niniejszego szkicu o Jadwidze i Wilhelmie, będę się starał podać inną, niż dotychczas to czyniono, interpretację stosunku węgiersko-polskiej Andegawenki do austriackiego księcia, opartą o całościową analizę źródeł dotyczących tej sprawy i zasadnicze odrzucenie - jako z małymi wyjątkami bezwartościowych dla oceny autentycznych wydarzeń - przekazọ́w ex fama.

\section{PRZEZNACZENIE JADWIGI NA ŻONE DLA WILHELMA}

Ludwik Andegaweński, król Węgier i Polski, dopiero po 18 latach od zawarcia małżeństwa doczekał się potomstwa z drugiej swej żony Elżbiety Bośniaczki. Pierwszym jego dzieckiem była Katarzyna ${ }^{3}$, którą ojciec przeznaczył układem z dnia 19 grudnia 1374 na żonę królewiczowi francuskiemu, a drugim Maria, która już w połowie 1373 r. ${ }^{4}$ była przyrzeczona Zygmuntowi Luksemburgowi, synowi cesarza Karola IV. Ludwik gorąco oczekiwał przyjścia na świat syna, któremu pragnął przekazać swoje dwa królestwa Węgier i Polski. Wbrew jego oczekiwaniom następnym i ostatnim jego dzieckiem była córka, której nadano imię Jadwiga. Wówczas książę rakuski Leopold III zwrócił się do Ludwika w dokumencie erenburskim z dnia 18 VIII 1374 z propozycją połączenia związkiem małżeńskim Jadwigi $\mathrm{z}$ jego najstarszym synem Wilhelmem; Ludwik potwierdził ten projekt aktem budzińskim z datą 4 marca $1475^{5}$. Jadwiga

2 Literature dotyczaca królowej Jadwi i dokładnie zestawił Romuald Gustaw przy artykule A. Strzeleckiej Jadwiga królowa, w: Hagiografia polska, Stownik biobibliograficzny (HP), t. I, Poznań 1971, 509-523.

${ }^{3}$ J. Dąbrowski, Ostatnie lata Ludwika Węgierskiego 1370-1382, Kraków 1918, 355.

4 W. Maciejewska, Jadwiga, królowa polska, „Przegląd Powszechny” (1934) zesz. dodat. nr III, (Maciejewska), 11.

5 Zaręczyny mogły być zawarte đrogą listowną, jak świadczy Ulpianus. Por. Justynian, Corpus Iuris Civilis I, Digestarum seu Pandectarum, Berolini 1963 (Dig), XXII, I, 18, s. 330: „In sponsalibus constituendis parvi refert per se (et coram an 
miała być przeto księżną austriacką. Na przyszłym połączeniu tych dzieci bardzo zależało tak Ludwikowi, jak i dworowi wiedeńskiemu. Habsburgowie poczęli wchodzić na drogę szczęśliwego układania małżeństw, które im bez prowadzenia wojen zaborczych pozwoliły zdobyć największe znaczenie monarsze na świecie i odziedziczyć liczne kraje od Siedmiogrodu do terytoriów amerykańskich. „Bella gerant alii, tu, felix Austria, nube”. Wejście w rodzinę potężnego Ludwika mogło im dać dużo ewentualnych korzyści. Tym się kierując Leopold w porozumieniu z Ludwikiem powziął zamiar połączyć swego 8-letniego syna Wilhelma i 4-letnią Jadwigą jeszcze ściślejszymi więzami przez urządzenie im uroczystości ślubnej w formie naśladującej sponsalia de praesenti ${ }^{6} \mathrm{z}$ dodaniem ceremonii towarzyszących rytowi małżeństwa. Spotkanie dzieci nastąpiło w pogranicznym Hainburgu, gdzie w kościele parafialnym arcybiskup ostrzyhomski Dymitr udzielił im 15 VI 1378 ślubu, a potem na zamku odbyły się ,,pokładziny", które wówczas należały do całości obrzędu ślubnego ${ }^{7}$. Prawdopodobnie przez okres dwu tygodni dzieci sypiały razem. Rodzice tak ze strony andegaweńskiej jak i austriackiej zobowiązali się wypłacić młodej parze po 200000 złotych (florenów) do dnia św. Jerzego w 1384 roku ${ }^{8}$. Posagiem Jadwigi miała być marchia trewizańska, o którą Austria prowadziła wojnę $z$ Wenecją ${ }^{9}$. W Hainburgu postanowiono również, że Jad-

per internuntium vel per epistolam) an per alium hoc factum est". Jadwiga i Wilhelm byli zaręczeni przez rodziców per epistolam już w roku 1375. Monumenta Hungariae Historica, Acta Extera Andegavensia III, Budapest 1886 (Extera), nr 73, s. 86. Podzial zareczyn na sponsalia de futuro i na sponsalia de praesenti wprowadził w połowie XII wieku Piotr Lombard, autor słynnych Sentencji. Sponsalia de praesenti mogli zawierać tylko puberes (chłopcy po ukończeniu 14 lat, a dziewcza ta po 12 latach). Sluby Wilhelma i Jadwigi, naśladujące sponsalia de praesenti były $\mathrm{W}$ istocie tylko ułożonymi przez rodziców zaręczynami de futuro. Zawarcie "ślubu" w latach dziecinnych dawało niewielką korzyść, bo tylko zwalniało od solemnizacji kościelnej po dojściu do lat sprawnych. Sponsalia de futuro, zawarte przez rodziców w imieniu dzieci, które nie ukończyły jeszcze 7 roku życia (przynajmniej jedno $z$ nich) nie były ważne, bo według wymagań prawa kościelnego promissio futuri matrimonii musi być voluntaria, mutua, aliquo signo externo sufficienter manifestatı. Zaręczyny takie uzyskiwały wtedy swą ważność, jeżeli oboje dzieci po skończeniu 7 roku życia wyrażały konsens na swoje narzeczeństwo. Ten konsens nie musiał być uroczyście składany, wystarczyło, jeżeli dzieci dobrowolnie i wzajemnie za narzeczonych się uważały. Konsens dany po 7 roku życia i consummatio matrimonii po osiagnięciu lat sprawnych (pubertas) czyniły narzeczonych malzonkami. Wilheim i Jadwipa, gdyby spełnili powyższe warunki, nie byliby obowazani na skutek ślubów hainburskich do udawania się do kościoła po błogosławienstwo. J. S. Felczar, Prawo matżérskie katolickie, Kraków 1885, 56.

"Quando Reverendissimus in Christo pater dominus Demetrius tunc archiepiscopus Strigoniensis, - eos Haimburgae in ecclesia parochiali cum debita solemnitate - ad invicem copulaverit ipsique ea nocte fuerint in uno lecto positi et coniuncti". G. Fejér, Codex diplomaticus Hungariae ecclesiasticus et civitis, Budapest 1834 (CDHung), t. IX, vol. 5, nr 202, s. 376.

CDHung, t. IX, vol. 5, nr 122, s. 255-257.

9 H. Pez, Scriptores rerum Austriacarum (SRA), Wien 1849, t. I, 384: „Unde factum $\epsilon \approx t$, ut Marchiam Tervisinam ct civitatem Tervisium iure bellico post diuturnam obsidionem tandem aliquando captam et obtentam duci Lsopoldo traderet: quod fiio sub rrimogenito duci Gwilhelmo - filiam suam iuniorem, nomine Hedvigem, legissime desponsasset, in cuius dotem dicta Marchia cedere deberet". 
wiga od razu wyjedzie $z$ zamku na dwór wiedeński, a Wilhelm zostanie przywieziony do Budy ${ }^{10}$. W nowym domu Jadwiga miała uzupełnić wykształcenie i wróść w tradycje habsburskiego kraju, gdzie prawdopodobnie miała pozostać na zawsze jako przyszła jego księżna.

\section{JADWIGA WYZNACZONA PRZEZ OJCA NA PRZYSZEA KROLOWE WĘGIER}

Jadwiga nie przebywała zbyt długo na dworze wiedeńskim. Królewską rodzinę w budzińskim grodzie dotknęła bowiem przy końcu roku 1378 ciężka żałoba $\mathrm{z}$ powodu śmierci najstarszej córki Ludwikowej Katarzyny, uważanej za pierwszą dziedziczkę ojcowskiego tronu. Przed Ludwikiem stanęła wówczas konieczność zmiany w sprawie sukcesji obojga królestw, jakie posiadał. Ludwik zwrócił się wówczas do Leopolda III, by odesłał do Budy Jadwigę. Około 1 czerwca 1379 roku książę austriacki odwiózł Jadwigę do stolicy Węgier ${ }^{11}$, wyrażając niezadowolenie, bo się obawiał, żeby Ludwik w nowej sytuacji nie wyszukał innego męża dla młodszej córki. Maria miała być królową Polski i dlatego w sierpniu 1379 r. Ludwik wezwał panów polskich do Koszyc, aby złożyli hołd Marii jako wyznaczonej na ich władczynię. Powodem tej desygnacji było może to, że narzeczony Marii Zygmunt Luksemburg przez matkę Elżbietę pomorską był w prostej linii prawnukiem Kazimierza Wielkiego. Nie jest wykluczone, że Ludwik, widząc wielką bystrość i inteligencję młodszego dziecka, pragnął je zachować dla kraju, który był bliższy jego sercu. Odegrał tu też rolę wzgląd geograficzny, bo Austria bezpośrednio łączyła się z królestwem Węgier. Związek Węgier z Austrią przełożył Ludwik nad powiązania z cesarską Pragą. Jadwiga, jako przyszła królowa Węgier, nie mogła Budzina opuszczać i więcej do Wiednia nie wróciła. W sercu Leopolda III obudził się niepokój, że wobec zmiany pozycji Jadwigi, która z kandydatki na księżną austriacką stała się przyszłą królową Węgier, Ludwik będzie dążył do odwołania ślubów hainburskich. Dlatego książę rakuski dążył do tego, by hainburskie zobowiązania Ludwikowe zostały potwierdzone na nowo. Rzeczywiście, na zjeździe w Zwoleniu 12 lutego 1380 roku Ludwik przyrzekł Leopoldowi, że jak tylko Jadwiga ukończy 12 rok życia, odeśle ją do Wilhelma, aby ich małżeństwo było dopełnione. Termin wpłaty kwot obiecanych dzieciom przez rodziców został przyspieszony o rok wcześniej, to jest na rok $138{ }^{12}$. Zwoleńską umowę podpisały prócz króla Ludwika obie królowe Elżbiety: Łokietkówna (która jeszcze w tym samym roku 29 XII 1380 zmarła) oraz Bośniaczka, a także szereg duchownych i świeckich w liczbie około 30 osób, między

10 CDHung, t. IX, vol. 5, nr 202, s. 377.

11 Extera III, nr 141, s. 178.

12 CDHung, t. IX, vol. 5 , nr 202, s. 376. 
nimi Władysław Opolczyk i Ziemowit III Mazowiecki. Jadwiga liczyła wtedy 6 lat $\mathrm{i}$ po powrocie $\mathrm{z}$ Wiednia $\mathrm{z}$ Wilhelmem się nie stykała ${ }^{13}$. Wkrótce potem Ludwik zrzekł się pretensji do Neapolu, który był brany $\mathrm{w}$ rachubę przy układaniu małżeństwa z królewiczem francuskim, i osadził tam swego krewniaka Karola de Pace w tej nadziei, że nie będzie zagrażał córkom w ich prawach do tronu węgierskiego (1380-1381).

Jadwiga, pozostawszy na budzińskim dworze, pobierała wraz z siostrą Marią wykształcenie potrzebne obu królewnom jako przyszłym monarchiniom. Wraz z siostrami andegaweńskimi uczyły się zapewne i dwie siostry Piastówny, córki Kazimierza Wielkiego, Anna i Jadwiga. W ich towarzystwie poznała Jadwiga mowę polską, prócz tego w ramach edukacji zdobywała znajomość języka łacińskiego i niemieckiego. Wysoką kulturą umysłową wybijał się i sam ojciec królewien węgierskich Ludwik, założyciel (w r. 1367) uniwersytetu w Peczu; jako syn Karola Roberta, Francuza z Neapolu, żywił zainteresowania intelektualne i artystyczne, związane $z$ wpływami dworu francuskiego i elity italskiej, co się odbiło bez wątpienia na urobieniu duchowym jego córek. Królewny spotykały się $\mathrm{z}$ bawiącymi na dworze węgierskim uczonymi, dyplomatami i mężami stanu; obserwacja wartko płynących zdarzeń politycznych uczyła je sztuki rządzenia państwem i przygotowywała do objęcia trudnych i odpowiedzialnych obowiązków wobec narodów, na których czele miały w tak młodym wieku stanąć. Długosz daje świadectwo o Jadwidze, że była „rzadkimi nad podziw wdziękami od natury ozdobiona, ćwiczona w naukach, układna w obejściu, zachowująca skromność i powagę, nie tylko urodzeniu swemu, ale i kobiecie właściwą" ${ }^{14}$. Ułożony rytm zajęć królewien, dzielący ich czas między poważne studium i lekturę, a także i udział w życiu dworskim, został w sierpniu 1382 gwałtownie przerwany przez niespodziewaną śmierć ich ojca - króla Ludwika.

\section{JADWIGA PRZECHODZI NA TRON POLSKI}

Zgon Ludwika Andegawena w r. 1382 osierocił dwa królestwa: węgierskie i polskie. To sieroctwo było złagodzone faktem wyznaczenia przez króla jeszcze za swego życia dwóch następczyń po sobie: Maria miała

13 Austriacki kronikarz Tomasz Ebendorfer, piszący w 1. 1452-1462 swe dzieło Chronicon Austriacum, SRA I, 819 podaje, że Ludwik Węgierski na krótko przed śmiercią miał wezwać Wilhelma do Tyrnawy, aby go tam przedstawić magnatom jako przyszłego króla Węgier. Z powodu rychłej śmierci Ludwika do tego nie doszło. Wiadomość ta jest zresztą niepewna, bo źródła węgierskie na jej temat zupełnie milczą.

14 "Cui etiam rarae eximiaeque speciei decorem a natura videbant donatum, doctam insuper literis, moribus eruditam, decoram non tantum genere quantum et feminea dignitate, moderatam natura, pudore quoque ingenuo singularem". J. Długosz, Opera omnia, XII: Historiae Polonicae, lib. IX, X, Kraków 1876, 449-450 (Długosz). 
objąć panowanie w Polsce, a Jadwiga na Węgrzech. Dyspozycję testamentu Ludwikowego zmienili sami Węgrzy, bo po pogrzebie królewskim okrzyknęli 17 września 1382 nowym królem na Węgrzech 11-letnią Marię ${ }^{15}$, która trzy lata temu w Koszycach (1379) odebrała już od panów polskich hołd, jako ich królowa. Węgrzy chcieli utrzymać związek Polski z Budą, bo bynajmniej nie dążyli do tego, by Maria z panowania w Polsce zrezygnowała. Maria została ukoronowana na króla Węgier, a Jadwiga w ten sposób została pozbawiona dziedziczenia po ojcu i pozostało jej tylko wyjść za Wilhelma i zadowolić się tytułem księżnej styryjskiej wśród plejady Habsburgów w krajach alpejskich. Leopold III jednak milczał i mimo śmierci Ludwika na razie nie żądał od Elżbiety Bośniaczki ponownego zatwierdzenia ślubów hainburskich. Nie tylko dla Habsburgów, ale i dla ośmioletniej Jadwigi było to silne przeżycie, gdy zauważyła, że się jej Węgrzy jako swojej królowej wyparli.

Wiadomość o koronacji Marii na króla węgierskiego, która była przecież uznanym królem Polski, zaskoczyła polskich panów. Zrozumieli grę Węgrów, którzy w ten sposób chcieli utrzymać rozszerzenie granic królestwa Węgierskiego na terytorium polskie. Szlachta polska pomna tego, że okres rządów Ludwika, nazwanego na Węgrzech Wielkim, dla zarządzanej przez jego namiestników Polski nie we wszystkim był pomyślny, na pierwszych dwóch zjazdach odbytych w czasie bezkrólewia, jednym zapowiedzianym przez Wielkopolan w Radomsku 25 XI $1382^{16}$ i drugim zwołanym przez Małopolan do Wiślicy 6 XII $1382^{17}$, uchwaliła, że tylko tej córce Ludwika dochowa wierności i posłuszeństwa, która będzie przeznaczona na królową i stale z mężem w Polsce zamieszka. Zygmunt Luksemburczyk, narzeczony Marii, którego bezkrólewie zastało w Polsce, widząc nadzieje na tron krakowski stracone, wyjechał z Polski.

Następne dwa zjazdy odbyły się w Sieradzu i miały decydujący charakter. W dniu 26 lutego 1383 r. ${ }^{18}$ przy jechało do tego miasta poselstwo królowej Elżbiety z Mikołajem biskupem weszpremskim na czele, które oświadczyło, że królowa zwalnia Polaków od zobowiązań złożonych Marii i Zygmuntowi Luksemburczykowi, a na tron polski wyznacza młodszą córkę Jadwigę. Po Wielkiejnocy przyśle ją do Polski w celu nałożenia na jej głowę korony, lecz stanowczo żądała, aby młodziutka królowa wróciła do niej na trzy lata w celu ukończenia edukacji. Na drugim zjeździe w tymże Sieradzu odbytym 28 marca $1383^{19}$ dano w sprawie kandydatury Jadwigi królowej Elżbiecie odpowiedź przychylną i ustalono przy-

15 A. Huber, Geschichte Österreichs, Gotha 1895, t. II, 325.

${ }_{16}$ Kronika Janka z Czarnkowa, w: Monumenta Poloniae Historica (MPH), II, wyd. A. Bielowski, Lwów 1872, nr 64, 723-724.

17 Tamże, 724 .

18 Tamże, nr 71, 732-733.

19 Tamże, nr 75, 735-736. 
jazd Jadwigi na dzień Zielonych Swiąt (10 maja). Sprawa obsady tronu krakowskiego byłaby załatwiona bez trudności, gdyby nie zamach na kandydaturę Jadwigi ze strony księcia mazowiecko-płockiego Ziemowita IV, którego popierał arcybiskup Bodzanta w nadziei utrzymania Piastów przy sterze państwa. Gdy się skończył drugi zjazd sieradzki, arcybiskup znienacka wysunął kandydaturę Ziemowita i wywołał entuzjazm dla jego osoby zwłaszcza wśród rycerstwa wielkopolskiego. Próbę elekcji udaremnił odważnym wystąpieniem Jaśko z Tęczyna, kasztelan wojnicki. Ziemowit, nie rezygnując $z$ nadziei otrzymania polskiej korony, przygotował plan porwania królewny, gdy na Zielone Święta miała wjeżdżać do Krakowa ${ }^{20}$, ale na próżno na tę chwilę oczekiwał ukryty w orszaku zbrojnym arcybiskupa Bodzanty koło kościoła św. Floriana, bo Jadwiga w ogóle nie przyjechała ${ }^{21}$. Wówczas Ziemowit zwołał zjazd do Sieradza 16 VI 1383 i tam, gdzie Jadwiga została ogłoszona polską królową, sam zarządził własną elekcję. Nie znalazł jednak szerokiego poparcia ${ }^{22}$. W sierpniu 1383 królowa wysłała przeciw Ziemowitowi 12000 wojska z Zygmuntem Luksemburczykiem na czele ${ }^{23}$. Mazowsze zostało spustoszone i Ziemowit zawarł rozejm ${ }^{24}$, zrzekając się pretensji do polskiej korony. Arcybiskup Bodzanta również przeszedł na stronę andegaweńską ${ }^{25}$. Zdawałoby się, że Jadwiga może teraz bezpiecznie przyjechać do Polski. Tymczasem na południu Węgier rozpoczęły się rozruchy, których sprawcy zamierzali oddać tron węgierski Karolowi Małemu, Andegawenowi z Neapolu. Aby czuwać nad bezpieczeństwem, Elżbieta udała się z córkami do Dalmacji, a margrabiemu Zygmuntowi poleciła obsadzić Wawel w charakterze gubernatora Polski. Te próby się jednak nie udały, bo Zygmunta zmuszono do opuszczenia kraju i więcej go do Polski nie wpuszczono. Z powodu przedłużającego się bezkrólewia na wiosnę 1384 panowie polscy uchwalili, że więcej żadnych posłów z prośbą o przybycie Jadwigi

20 Tamże, nr 77 i 78, 737-738.

21 Ziemowit IV miał zapewne zamiar zaręczyć się z królewną, bo o ślubie z 9-letnią dziewczynką nie mogło być mowy. Na taki ślub nie godziło się żadne prawo, ani nie udzielało dyspensy. Książę mazowiecki pragnął więc przyjąć koronę królewską obok Jadwigi jako swej narzeczonej.

22 Kronika Janka z Czarnkowa, nr 82, 739-740.

23 Tamże, nr 89, 743-744.

24 Rozejm brzeski na Kujawach został zawarty za pośrednictwem Władysława Opolczyka 6 X 1383. Tamże, nr 102, 748-749.

25 Arcybiskup Bodzanta musiał się oczyszczać od zarzutu zdrady przed kardynalem Dymitrem, arcybiskupem ostrzyhomskim; Maciejewska, 32. Popierając Ziemowita, oddał jednak mimo woli usługę dziełu unii polsko-litewskiej, bo zwrócił uwagę całego rycerstwa na to, że Polska nie musi się liczyć z zaręczynami Jadwigi z Wilhelmem, o których Jaśko z Tęczyna mówił jeszcze na drugim zjeździe sieradzkim 28 III 1383. Po zerwaniu unii z Węgrami na zjeździe w Radomsku 25 XI 1382 r. przyszła kolej na zerwanie związku z Austrią. Po nieudanej elekcji Ziemowita na trzecim zjeździe sieradzkim 16 VI 1383 pojawiła się i rozwijała myśl wybrania na męża dla Jadwigi księcia Litwy i Rusi, Jagiełły. 
do Elżbiety węgierskiej nie będą posyłali i ostatecznie wyznaczyli dzień 22 września na zjazd elekcyjny do Sieradza w celu obioru nowego króla ${ }^{26}$. Bośniaczka; widząc powagę sytuacji, którą jej przedstawił już nie jako poseł, ale jako prywatny gość, Spytek z Melsztyna, gorliwy zwolennik dynastii andegaweńskiej, wysłała wreszcie Jadwigę do Polski w lecie 1384 roku. Nie znamy dokładnie terminu jej przybycia do Krakowa, w. każdym razie z końcem lata mieszkała już na Wawelu 27.

\section{PRZYJAZD JADWIGI ANDEGAWEŃSKIEJ DO POLSKI I JEJ KORONACJA}

Jadwiga przekroczyła granicę polską - podobnie jak jej węgierska poprzedniczka na tronie krakowskim, błogosławiona Kinga, żona Bolesława Wstydliwego - na przełęczy dukielskiej w Karpatach.

Młodziutka władczyni jechała w orszaku danym jej przez żegnająca ją Bośniaczkę, która jako opiekunów przydzieliła córce kardynała Dymitra ostrzyhomskiego i biskupa z Csanád Jana. Na spotkanie Jadwigi wyjechali polscy panowie, dostojnicy małopolscy i zwolennicy utrzymania tronu przy dynastii andegaweńskiej. Spotkanie z tymi panami było dla Jadwigi radosne, ponieważ ich twarze znała $\mathrm{z}$ dworu budzińskiego, na który niejednokrotnie jako posłowie przybywali. Zapewne znalazły się wśród witających niektóre panie polskie zbliżone do rodziny Ludwika Wielkiego. Za orszakiem królewny jechały wozy z jej wyprawą.

Jadwiga $\mathrm{z}$ zaciekawieniem spoglądała na kraj i przedstawicieli tego narodu, z którym miała związać dalsze swe życie. Do jej uszu dochodzily dźwięki mowy polskiej, znanej jej z ust babki Elżbiety Łokietkówny, kuzynki Anny, a zapewne i niejednego bywalca na dworze jej ojca. Zacie-

26 Maciejewska, 31-37.

27 Jadwiga przyjechała do Polski po 25 maja 1384, bo w tym dniu, jak świadczą Najstarsze księgi rachunkowe miasta Krakowa (w: Monumenta medii aevi historica (MMedAev), IV, Kraków 1878, 59), wykonano egzekucję winowajczyni, przyspieszając ją „per adventum reginae”, z czego nie możemy wnioskować, znając tendencję Elżbiety węgierskiej do ociągania się, że Jadwiga wkrótce przyjechała. W Kodeksie dyplomatycznym Wielkopolski (KDWp), III, Poznań 1879, s. $351 \mathrm{nr}$ 1, 1825 spotykamy dokument wydany w Krakowie przez Jadwigę, odnoszący się do procesu arcybiskupa Bodzanty dnia $11 \mathrm{X}$ 1384, a więc 4 dni przed koronacją. Ponieważ koronację odbywano w obecności przedstawicieli wszystkich ziem polskich, których trzeba było zawiadomić, dać im czas na przyjazd do Krakowa i samą uroczystość trzeba było przygotować, dlatego można się liczyć z tym, że od przybycia Jadwigi do koronacji upłynęło około półtora miesiąca. Skoro przyjmiemy, że koronacji bez potrzeby nie odkładano, najbardziej prawdopodobnym terminem przyjazdu Andegawenki będzie koniec sierpnia 1384 roku. Ostatnio pojawiła się w nauce hipoteza, że obraz Matki Boskiej Częstochowskiej był przywieziony przez królowę Jadwigę do Polski. Według tradycji paulińskiej data translacji obrazu jest dzień 31 sierpnia 1384. Termin ten może potwierdzać czas, w którym Jadwiga pokazała się na ziemi polskiej. Maciejewska, 38. K. Pieradzka W recenzji prac W. Maciejewskiej i A. Strzeleckiej, „Kwartalnik Historyczny”, 49 (1935) 408; E. Snieżyńska-Stolot, Geneza, styl i historia obrazu Matki Boskiej Częstochowskiej. „Folia Historiae Artium” t. IX, Kraków 1973, 41-42. 
kawione zaś oczy witających podziwiały jej młodość, urodziwą twarzyczkę, a zarazem powagę, płynącą ze świadomości swej roli, pogłębioną.przeżyciami, jakich nawet tak krótkie życie jej nie szczędziło, jej pokorę i prostotę, nie usiłującą podkreślać wyższości monarszej, łagodność i dobroć, której miała później okazać liczne dowody ${ }^{28}$.

Po przybyciu do stołecznego miasta Jadwiga zamieszkała na zamku królewskim na Wawelu. Dłuższy czas trwały przygotowania do koronacji. Termin ustalono na połowę października. Prawdopodobnie koronę królewską otrzymała w dniu swej patronki św. Jadwigi, księżnej śląskiej, 15 października $1384{ }^{29}$. Koronatorem był arcybiskup gnieźnieński Bodzanta (który $11 \mathrm{X}$ oczyszczał się od zarzutu zdrady w związku z popieraniem na tron polski Ziemowita IV księcia mazowieckiego ${ }^{30}$, a asystowali kardynał Dymitr, arcybiskup ostrzyhomski, Jan Radlica biskup krakowski i Jan biskup z Csanád. Jako spadkobierczynię tronu Łokietka i Kazimierza Wielkiego i ,panią naturalną” Polski arcybiskup ukoronował Jadwigę na króla ${ }^{31}$, a nie na królową. Mimo, że była małoletnia, nie miała jednak przy boku żadnej regencji, lecz sama w swym imieniu

28. „Nec mirum: noverant enim illam ita educatam atque institutam esse ab annis teneris, ut formam honestas, speciem pudor, pulchritudinem virtutes, gloriam et divitias continentia atque modestia, potentiam mansuetudo antecellerent". Długosiz, 449.

29 Koronacja Jadwigi zapisana jest w Kalendarzu krakowskim (MPH II, 934 i VI, wyd. W. Bruchnalski, Kraków 1893, 658) pod dniem 15 X 1384, ale pisarz opisujący to wydarzenie zaznaczył, że to był dies dominicus, podczas gdy w $1384 \mathrm{r}$. była to sobota. A. Misiąg-Bocheńska w artykule Dwie daty z życia królowej Jadwigi, "Polonia Sacra" 2 (1949) 267-275, opowiedziała się za terminem koronacji $\mathrm{w}$ niedzielę $16 \mathrm{X}$, gdyż było zwyczajem, że koronacje królów polskich odbywały się w dniu niedzielnym. Zapiskę w Kalendarzu krakowskim uważa nie za podpisaną pod $15 \mathrm{X}$, lecz nadpisaną nad $16 \mathrm{X}$. Argumentacja Bocheńskiej jest bardzo ważka i nie można jej lekceważyć.

Broniąc powszechnie przyjętego (również przez Długosza) terminu koronacji Jadwigi w dniu $15 \mathrm{X}$, można wysunąć następujący wywód: a) możliwość pomyłki notariusza, który zapisując notatkę w Kalendarzu po pewnym czasie miał wrażenie, że w dniu koronacji była niedziela, bo dzień św. Jadwigi Sląskiej z polecenia abpa Janusza na synodzie W Pajęcznej (1269) obchodzono uroczyście. Por. B. Suchoniówna, Jadwiga Sląska (HP I, 468); K. Szajnocha, Jadwiga i Jagiełlo, I-II, Warszawa 1969, 704-706, b) wszystkie inne zapisy podają dzień św. Jadwigi jako termin koronacji, Rocznik mansjonarzy krakowskich (tzw. Swiętokrzyski), MPH Iwów 1878, 81. „Hedvigis [...] coronatur in regem Polonie in die sancte Hedvigis in ecclesia cathedrali". J. Dąbrowski, Dawne dziejopisarstwo polskie (do roku 1480), Wrocław - Warszawa - Kraków 1964, 57-60, c) sam fakt wpisu w Kalendarzu krakowskim pod $15 \mathrm{X}$. Jeżeli notariusz zamierzał dać swój zapis, należący do $16 \mathrm{X}$, ponad dniem św. Galla, winien był w tekście swej informacji podać nie tylko dzień tygodnia, ale i dzień miesiąca, by wyraźniej zaznaczyć, że notatka należy do innego dnia.

30 KDWp III, nr 1826.

31 Kalendarz krakowski: ,in regem Polonie coronata"; Rocznik Świętokrzyski, 81: ,coronatur in regem Polonie [1]". S. Kutrzeba, Ordo coronandi regis Poloniae, Kraków 1910, 83-84: J. Dąbrowski, Królowa Jadwiga, „Przegląd Powszechny", 200 (1933) 206; Maciejewska, 38; H. Quillus, Königin Hedvig von Polen, Slavische Forschungen, H. 2, Leipzig 1938, 27. Podobnie starsza siostra Jadwigi, Maria, zaraz po śmierci ojca była ukoronowana na króla węgierskiego. CDHung t. $\mathrm{X}$, vol. $1, \mathrm{nr} 1$, s. 38; A. Huber, Geschichte Osterreichs, II, 325. 
wykonywała władzę. Będąc wszakże w młodym wieku, nie znając kraju i polskich spraw państwowych, nie mając żadnego doświadczenia, całkowicie polegała na radzie i decyzjach otaczających ją panów krakowskich, do których miała całkowite zaufanie. Mając 10 lat i 8 miesięcy mogła przy swej wielkiej inteligencji poznać przywiązanie i oddanie swych dygnitarzy tak dla dynastii, jak i dla jej osoby, oraz ich głęboką troskę o losy kraju. Nie ulega wątpliwości, że wytrawni politycy, stojący przy tronie młodocianej monarchini, informowali ją o wszystkich wydarzeniach państwowych i zaprawiali do objęcia w przyszłości samodzielnych rządów nad Polskim Królestwem.

\section{POSELSTWO KSIECIA LITEWSKIEGO JAGIEEŁY Z PROSBA O REKKE KRÓLOWEJ JADWIGI}

Koronacja Jadwigi nie załatwiła definitywnie obsady tronu krakowskiego, wiadomą było rzeczą, że Jadwiga musi znaleźć towarzysza życia i współrządów. Po upływie roku i 4 miesięcy królowa miała się stać zdolną do małżeństwa, dlatego nadchodził już czas wyboru dla niej małżonka, ułożenia z nim warunków, pod którymi jej małżeństwo będzie zawarte, doprowadzenia do przyzwolenia narodu i elekcji przyszłego męża na króla polskiego. Można było przewidywać, że ułożenie warunków małżeństwa i przygotowanie na nie rycerstwa polskiego będzie wymagało wielu poselstw i układów.

Panowie polscy dobrze wiedzieli o ślubach hainburskich Jadwigi, ale jej mariaż z Wilhelmem rakuskim stanowczo wykluczyli. Leopold III, ojciec Wilhelma, poniósł zupełną klęskę, bo na Węgrzech nie przyjęto na króla Jadwigi jako narzeczonej jego syna, lecz koronę nałożono na głowę Marii zaręczonej z Zygmuntem Luksemburgiem, w Polsce zaś panowie postanowili sami wybrać męża Jadwidze, ignorując zobowiązania powzięte przez jej rodziców ${ }^{32}$. Nie trudno im przychodziło zyskać dla swych zamiarów zgodę Jadwigi, bo na dworze budzińskim była ona przez matkę swą Elżbietę wychowaną w oddaleniu od Habsburgów. Może już nad Dunajem Jadwiga $w$ sekretnych rozmowach posłyszała od matki o zamiarach panów polskich wydania jej za księcia litewskiego Jagiełłę, który właśnie w tym czasie silnie umocnił swą władzę na Litwie i Rusi.

32 Zamiary swe co do wyboru męża dla Jadwigi mogli polscy panowie przedstawić Elżbiecie na IV zjeździe koszyckim w maju 1383 odprawionym w czasie powodzi, która przeszkodziła w przyjeździe młodej królowej do Polski w Zielone Swięta. Zjazd był liczny, atmosfera bardzo serdeczna. Panowie zgodzili się nawet na powtórne połączenie Polski i Węgier na wypadek bezpotomnej śmierci jednej z córek Elżbiety. Przypuszcza się, że wówczas wyłączyli kandydaturę Wilhelma do ręki Jadwigi. Późniejszy upór Elżbiety, która odmawiała wysłania Jadwigi do Polski, zepsuł tę harmonijną współpracę panów polskich z Elżbietą. Kronika Janka z Czarnkowa, nr 76, 736. 
Jest rzeczą bardzo prawdopodobną, że rokowania z Jagiełłą były rozpoczęte za wiedzą matki Elżbiety i córki Jadwigi już wtedy, gdy obie jeszcze razem przebywały na zamku w Budzie ${ }^{33}$. Jadwiga związana z matką propozycję przyjęła i jechała do Polski przygotowana do małżeństwa z Jagiełłą. Po koronacji królowej rozmowy i rokowania z Jagiełłą szybko sfinalizowano i w trzy miesiące później dnia 18 stycznia 1385 roku przyjechało do Krakowa świetne poselstwo litewskie ${ }^{34}$ prowadzone przez pełnomocnika książęcego Skirgiłłę, wiozącego bogate dary, jak to bywało w zwyczaju swadziebnym. Skirgiełło, któremu towarzyszyli książęta jego kraju Olgimunt i Borys oraz liczny zastęp bojarów litewskich, prosił przy złożeniu darów Jadwigę, by zgodziła się oddać rękę jego bratu Jagielle, wielkiemu księciu Litwy i Rusi, dodając, że z okazji małżeństwa on sam i cały jego naród przyjmą chrześcijaństwo. Prośbę swą poselstwo skierowało również do otaczających królowę przedstawicieli szlachty polskiej ${ }^{35}$.

Dla królowej Jadwigi propozycja posłów Jagiełły nie była z pewnością niespodzianką. O zamiarach połączenia jej węzłem małżeńskim z wielkim księciem litewskim wiedziała - jak wyżej wspomniano od swej matki, gdy jeszcze przebywała na Węgrzech. Przez panów colskich była poinformowana, że w oznaczonym terminie przybędzie do niej poselstwo od Jagiełły.

Odpowiedź Jadwigi na prośbę poselstwa litewskiego niezawodnie była ułożona z jej doradcami. Królowa propozycji małżeńskiej nie odrzuciła, ale odwołała się do przepisów prawa. Jako małoletnia nie mogła o swym małżeństwie decydować bez wiedzy i zgody swej opiekunki, jaką była dla niej matka. Dlatego za radą publiczną panów do niej odesłała poselstwo.

33 O tych projektach małżeńskich Elżbieta Bośniaczka i jej córka dowiedziały się później w maju 1384, gdy na Węgry pojechał bezgranicznie oddany dynastii andegaweńskiej Spytek z Melsztyna $z$ ostrzeżeniem o powadze sytuacji na wypadek dalszego zatrzymywania się Jadwigi przy matce. W dniu 22 września miała się odbyć w Sieradzu elekcja króla polskiego z pominięciem Jadwigi. Kronika Janka z Czarnkowa nr 115, 754-755; Maciejewska, 36.

${ }_{34}, 18$ januarii 1385. Anno Domini MCCCLXXX quinto Sgergelo, Olgemont et Borizszo duces Lithwanie cum multo comitatu Cracoviam intrantes, Hedvigi regine Polonie in regem coronate, munera non modica obtulerunt et a nobilibus regni Polonie ipsam Hedvigim Jagelloni magno duci Lithwanie in uxorem postularunt, fidem Christi assumere cum eorum subditis promittentes, antequam huius modi contractus celebraretur. Sed nobiles terre Polonie ad Ungariam pro consensu et voluntate domine Elizabeth matris eius legatos et nuncios proprios cum nunciis Lithwanorum remiserunt”. Kalendarz krakowski, MPH VI, 658.

35 Kuczyński słusznie przypuszcza, że posłowie litewscy nie rozwijali przed królową Jadwigą wszystkich warunków małżeństwa, wymienionych $\mathrm{w}$ akcie krewskim. Zapiska Kalendarza krakowskiego o złożeniu darów świadczy, że posłowie swą prośisę wobec niej przedłożyli, przyrzekając chrzest poganina Jagiełły. Inne warurki były przcdmiotem dalszych rozmów kierownika poselstwa Skirgiełly i panów polskich. Panowie wyznaczyli swych posłów do królowej Elżbiety na Węgry. Kuczyński, 225. 
Jagiełło dobrze wiedział o tym, że młodziutka królowa krakowska nie jest pełnoletnia i z góry był przygotowany na odpowiedź, jaką Jadwiga dała Litwinom. Dlatego wysyłając do Krakowa Skirgiełłę jako swego plenipotenta, dał mu władzę subdelegowania danych mu upoważnień stosownie do okoliczności. Skirgiełło skorzystał z tego, bo pozostając z Olgimuntem w Krakowie, wysłał do królowej matki na Węgry, jako przedstawiciela wielkiego księcia, członka rodu Borysa, któremu miał towarzyszyć Hanko-Hanul, starosta wileński.

Możnowładcy polscy dodali im asystę w osobach swych posłów Włodka z Charbinowic i Ogrodzieńca, Mikołaja Bogorii cześnika krakowskiego i Krystyna z Ostrowa, dzierżawcy (tutor) kazimierskiego.

\section{POSELSTWO LITEWSKO-POLSKIE DO KRÓLOWEJ WĘGIERSKIEJ}

Posłowie litewscy, z którymi połączyli się przedstawiciele panów polskich, mieli przed sobą daleką drogę do matki królowej Jadwigi. Na terenie Węgier otrzymali wiadomość, że Elżbieta Bośniaczka wyjechała do Slawonii, gdzie w miejscowości Pożega miała przebywać kilka miesięcy. Powodem wyjazdu królowej do zachodnich stron swego państwa były wszczęte na nowo układy w sprawie małżeństwa jej starszej córki Marii, już ukoronowanej na królową Węgier, z królewiczem francuskim Ludwikiem Orleańskim. Posłowie francuscy nadjechali do Pożegi z końcem lutego 1385 roku, a niedługo po nich, a więc około początku marca, zjechało do miasta poselstwo litewsko-polskie ${ }^{36}$.

Wysłannicy litewscy $\mathrm{w}$ obecności trzech polityków polskich przedstawili matce prośbę wielkiego księcia o rękę jej córki i wyłożyli obietnice, jakie starający się książę. zamierzał złożyć z okazji spodziewanego małżeństwa ${ }^{37}$.

Swe przemówienie rozpoczęli od pochwały Jagiełły i podkreślenia jego znaczenia, wykazując, że wielu cesarzy, królów i książąt pragnęło być spokrewnionymi $\mathrm{z}$ ich księciem, lecz staje się to dopiero udziałem królowej węgierskiej. Prosili w dalszym ciągu Elżbietę, ażeby przyjęła Jagiełłę za swego syna, dając mu za żonę najdroższą córkę Jadwigę, królowę polską. Posłowie oświadczyli, że w związku z tym małżeństwem Jagiełło przyrzeka przyjąć chrzest wraz z braćmi jeszcze nieochrzczonymi, krewnymi, bojarami (nobiles) i wszystkimi mieszkańcami Litwy według obrządku rzymsko-katolickiego. I znów podkreślili, jak wielki dynastię andegaweńską spotyka zaszczyt, że dokonuje tego, czego nie

36 Maciejewska, 46

${ }_{37}$ Akta Unii Polski z Litwa 1385-1791, wyd. S. Kutrzeba i W. Semkowicz, Kraków 1932, nr 1, s. 1-3. 
mogli uzyskać cesarze i książęta, mianowicie, że dzięki niej Jagiełło skłonił się do chrześcijaństwa ${ }^{38}$.

W dalszym ciągu wysłannicy Jagiełły w imieniu swego pana przyrżekali, że pod warunkiem małżeństwa $\mathrm{z}$ Jadwigą użyczy swych pieniędzy na zaspokojenie wszelkich braków w Królestwie Polskim, jak i w Wielkim Księstwie Litewskim, szczególnie podejmie się spłacenia vadium w wysokości 200 tysięcy złotych, które zostało ustanowione między królową Węgier a księciem austriackim ${ }^{39}$. Ponadto - według deklaracji posłów - Jagiełło zobowiązał się wszystkie ziemie Królestwa Polskiego, przez kogokolwiek zajęte i oderwane od Polski, własnym trudem i kosztem przywrócić, jeńców zaś polskich, uprowadzonych na mocy zwyczaju wojennego z ziem Królestwa Polskiego, obdarzyć wolnością, by mogli wrócić do stron rodzinnych. Najważniejsze oświadczenie zostawili mówcy litewscy na koniec, a było nim zobowiązanie się Jagiełły do przyłączenia (applicare) wszystkich ziem Litwy i Rusi do Korony Królestwa Polskiego.

Posłanie Jagiełłowe i przedstawione warunki (legationes) znalazły życzliwe przyjęcie u głównego doradcy Elżbiety węgierskiej palatyna Mikolaja Gary.

Po kilku dniach oczekiwania poselstwo litewsko-polskie otrzymało odpowiedź od królowej, że ,zezwala chętnie na wszystko, co by było z pożytkiem dla wiary i dla Królestwa Polskiego i godzi się na to, aby jej córka królowa Jadwiga oraz prałaci i panowie polscy to uczynili, co

ss O nawrócenie Litwy starało sie papiestwo (Innocenty IV zezwolił na koronację Mendoga 1253), cesarstwo (Karol IV), Polska (Władysław Łokietek oddziaływal w tym duchu na Giedymina 1275-1341), prawosławie (1383-1384), wreszcie ogniem i mieczem posługujący się Krzyżacy. Do chrześcijaństwa przywiodła Litwę dopiero dynastia andegaweńska. W. Abraham, Polska a chrzest Litwy, w: Polska $i$ Litwa $w$ dziejowym stosunku, Warszawa 1914, 8-9; K. Chodynicki, Próby zaprowadzenia chrześcijaństwa na Litwie, „Przegląd Historyczny”, 18 (1914); Kuczyński, 225.

${ }_{39} \mathrm{Tu}$ zaszło nieporozumienie, bo pakt w sprawie małżeństwa Jadwigi i Wilhelma zawarty 15 VI 1378 r. w Hainburgu, jak i jego odnowienie 12 II 1380 w Zwoleniu, przewidywał złożenie przez rodziców Jadwigi 200000 zł posagu, jak również przez rodziców Wilhelma wiana $w$ tej samej wysokości. Nie była to żadna kara konwencjonalna na wypadek zerwania małżeństwa. Nie złożenie tych sum w roku 1383, jak przewidywała umowa w Zwoleniu, jest dowodem, że po śmierci Ludwika (1382) sprawa małżeństwa Jadwigi z Wilhelmem uległa zawieszeniu i ich narzeczeństwo nie było aktualne. $\mathrm{Z}$ biegiem czasu zorientowano się w Polsce, że między królową Węgier a księciem Austrii nie było ustanowionego żadnego vadium czyli kary konwencjonalnej. Nie mogło ono być wyznaczone, bo prawo kościelne zabraniało takiej praktyki, gdyż zrywający zaręczyny, np. z powodu niemoralnego prowadzenia się drugiej strony, byłby niesprawiedliwie karany. "Sponsalibus apponi non potest poena solvenda ab eo, qui non steterít sponsalibus, quia hoc repugnat libertati matrimonii". M. Bonacina, Theologia moralis, Lugduni 1624, I, s. 250, nr 1 et seq. (Bonacina). Narzeczeństwo obowiązywało tylko $\mathrm{w}$ sumieniu jako res gravis momenti i jako quoddam sacramentale. Por. S. Thomae Aquin., Summa Theol., supplementum partis III-tiae, qu. XLIII, a. 1, ad 6. Po wyjaśnieniu kwestii rzekomego vadium żadna suma pieniężna z Polski do Austrii nie odpłynęła. 
uznają za dobre i zbawienne dla chrześcijaństwa i swej Rzeczypospolitej" ${ }^{40}$.

Odpowiedź królowej matki miała sens pozytywny. Dowodzi tego fakt, że z powracającym do Krakowa poselstwem litewsko-polskim Elżbieta wysłała dwóch swoich pełnomocników, Stefana proboszcza czanadzkiego i Władysława de Kaza, kasztelana $z$ Potoku ${ }^{41}$ do dalszego pertraktowania z Jagiełłą ${ }^{42}$.

$\mathrm{Na}$ wieść o powrocie posłów zwołano zjazd szlachty do Krakowa na początku lata 1385 r., na którym młodziutka królowa, okazując wielki ponad wiek rozsądek ${ }^{43}$, wyraziła gotowość zostania żoną księcia Jagiełły. Zjazd wysłał na Litwę posłów z pomyślnymi wiadomościami i z poleceniem przeprowadzenia z Jagiełłą oficjalnych układów małżeńskich.

\section{NA DWORZE HABSBURSKIM}

Habsburgowie $z$ pewnością uważnie śledzili przebieg wypadków w Krakowie. Jasną było dla nich rzeczą, że korona polska, której się od roku 1383 spodziewali dla Wilhelma, wymyka się im z rąk. Niepomyślnym dla nich faktem było stanowisko panów polskich, którzy przyjmując desygnację Jadwigi na tron polski zastrzegli, że oni sami wybiorą męża dla niej, ignorując tym samym zawarte między Leopoldem III a Andegawenami układy w sprawie jej małżeństwa z Wilhelmem: erenbursko-budziński z r. 1375, hainburski z r. 1378 i zwoleński z r. 1380. Jeszcze gorsze było to, że sama matka Jadwigi, Elżbieta Bośniaczka, unieważniła zabowiązania nieboszczyka męża, szukając dla swych córek innych partii niż te, które wyznaczył król Ludwik, i nie kwapiła się do dania jakichkolwiek gwarancji tak dla Zygmunta Luksemburga, narzeczonego Marii, jak i dla Wilhelma, narzeczonego Jadwigi. Oba rody niemieckie, Luksemburgowie i Habsburgowie, czekały odpowiedniej chwili, aby narzucić swoje zamiary matce obu królewskich latorośli.

40 „Elisabeth Hungariae regina respondet: se ad omnia, quae in fidei et Regni Poloniae profectum cederent, benivolam esse, contentamque fore, ut filia sua virgo regia Hedvigis, praelatique et barones Poloniae id agant, quod e re publica christianitatis et sua profutura duxerint". Długosz, 452.

41 J. Długosz dwa razy w swej Historii Polskiej wspomina „Pothok, oppidum Hungariae", IV, 653 i V, 279.

49 Obaj posłowie Bośniaczki, którzy przez dłuższy czas przebywali w Krakowie (przynajmniej przez 4 miesiące), byli z pewnością skierowani także do królowej Jadwigi, by jej objaśnić wolę matki. Przez ten czas Jadwiga przygotowywała się do małżeństwa z Jagiełłą. Poznała wtedy z pewnością i warunki, pod jakimi Jagiełło ma otrzymać jej rękę i cieszyła się nadzieją, że naród litewski dojdzie dzięki niej do chrześcijaństwa, że kilkudziesięciu jeńców polskich będzie zwolnionych z niewoli litewskiej, że przez odzyskanie oderwanych terenów i przyłączenie Litwy Polska będzie potężnym pańsțem.

43 "Quae infantiae annos egressa, ita mature et graviter sapere coepit, ut quicquid diceret, quicquid faceret, ex anili gravitate manare videretur". Długosz 450 . 
Już im nie chodziło o potwierdzenie zaręczyn, ale wprost o zawarcie małżeństwa $\mathrm{z}$ jej córkami. Jeżeli chodzi o Marię, nie było trudności, gdyż już posiadała odpowiedni wiek. Co do małoletniej Jadwigi trzeba było szukać stosownych sposobów prawnych, które by dopuszczały wcześniejsze zawarcie przez nią związku małżeńskiego.

Około połowy roku 1385 przyszły na Bośniaczkę ciężkie dni. Zygmunt Luksemburg nie chcąc dopuścić do tego, ażeby królewicz francuski, któremu królowa węgierska sprzyjała, zabrał mu Marię, przygotował wyprawę wojenną, ażeby na Elżbiecie wymusić oddanie mu córki. Zaś możnowładztwo południowych ziem królestwa pod wodzą rodu Horvathich dążyło do wprowadzenia na tron węgierski neapolitańskiego króla Karola z Durazzo. Szczęk broni niemieckiej od zachodu i bunt od południa skłonily Bośniaczkę do ustępstw na rzecz Habsburgów. Mimo że przed blisko pięciu miesiącami (na początku marca) wyraziła w Pożedze zgodę na małżeństwo Jadwigi z Jagiełłą, obecnie zmuszona okolicznościami podpisała w dniu 29 lipca wobec Leopolda III zobowiązanie, potwierdzone przez córkę Marię, kardynała Dymitra, palatyna Mikołaja Garę i księcia Władysława Opolczyka w sprawie dopełnienia przez Jadwigę małżeństwa $\mathrm{z}$ Wilhelmem. Było to nawiązanie do układu zawartego przez Ludwika w r. 1380 w Zwoleniu, lecz po jego śmierci (1382) zlekceważonego przez Elżbietę. Układ zwoleński przewidywał, że strona więgierska odeśle Jadwigę Wilhelmowi po skończeniu przez nią 12 lat. Obecnie to stało się niemożliwe, bo Jadwiga była królową w Krakowie ${ }^{44}$. W czwartym już z rzędu układzie budzińskim z r. 1385 postanowiono nie czekać, aż polska królowa skończy 12 lat, lecz dopełnienie małżeństwa przyspieszyć o sześć miesięcy, według zdania św. Tomasza z Akwinu, który określa czas uprzedzenia tak kontraktu narzeczeństwa (sponsalium) jak i małżeństwa na „tempus sex mensium”. Dokument budziński nie wspomina o latach Jadwigi, lecz poleca dokonać pokładzin „infra hinc et festum Assumptionis beatae Virginis" ${ }^{45}$. Zwrot ten w literaturze naukowej tłu-

44 ,Ita obligavimus - quod dictum matrimonium volumus et debemus fideliter perficere et ratum habere et eandem filiam nostram, cum ad duodecimum aetatis annum perveniret, predicto duci Wilhelmo iterum apponere, ut simul habitent et coniugaliter invicem vivant". Z Dokumentu zwoleńskiego 12 II 1380. CDHung, t. IX, vol. $5, \mathrm{nr} 202$, s. 376 .

45 „Parentelam et matrimonium inter Hedvigim et Vilhelmum plene et integre perficere volumus ipsosque in thoro nuptiali corporaliter componere et cohabitare permittemus et permittere volumus secundum statuta et consuetudines veri, iusti et legalis matrimonii et sacramenti matrimonialis, infra hinc et festum Assumptionis Beatae Virginis de mense Augusti proxime affuturum - committimus vobis Illustri Principi domino Ladislao duci Opolie - avunculo nostro carissimo, dando et elargiendo vobis plenam et integram potestatem, quatenus praefatum matrimonium infra Hedvigim filiam et sororem nostram duci Wilhelmo apponatis et in thoro nuptiali collocetis - detisque eis locum et copiam coniacendi, prout ad matrimonialiter conviventes pertinet et in hac parte nullam facietis dilationem". Akt budziński z 29 VII 1385, CDHung, t. X, vol. 1, nr 75, s. 141; nr 119, s. 228. 
maczy się błędnie: „najdalej do 15 sierpnia”, tymczasem według ówczesnego sposobu wyrażania się $\mathrm{w}$ języku łacińskim oznacza on , w sam dzień Wniebowzięcia NMP”. Można się tu posłużyć analogią z łaciny sądowej „dilatio causae infra hinc et octavam, infra hinc et quindenam” oznacza, że dalszy ciąg rozprawy odbędzie się za tydzień, za dwa tygodnie. Był to terminus praefixus (stały). Wyznaczenie terminu na 15 sierpnia daje do poznania, że to był pierwszy dzień szóstego miesiąca przed 12 rocznicą urodzin Jadwigi, czyli tym samym, że Jadwiga urodziła się 15 lutego $1374^{46}$. Pełnomocnikiem do wykonania tego zobowiązania był ustanowiony aktem budzińskim Władysław Opolczyk. Komisarz miał zalecony pośpiech, bo Habsburgom było wiadomo, przynajmniej od tego czasu, kiedy poselstwo litewsko-polskie stanęło w Pożedze (marzec 1385), że panowie polscy układają małżeństwo Jadwigi z Jagiełłą. Mocodawcy budzińscy spodziewali się jednak, że Władysław Opolczyk, jako Piast i krewniak dynastii, wasal Korony Królestwa Polskiego i przedstawiciel królowej Elżbiety, uzyska wstęp ze swym pupilem na Wawel i zaprowadzi go do królowej, jako jej narzeczonego.

\section{PRZYBYCIE WILHELMA DO KRAKOWA}

Królowa Jadwiga i panowie krakowscy dowiedzieli się o deklaracji budzińskiej $\mathrm{z}$ dnia 29 lipca 1385 roku zapewne dopiero po przybyciu Władysława Opolczyka i księcia Wilhelma do stolicy polskiej. Była ona dla otoczenia królowej niespodzianką, bo nie było rzeczą tajną, że po śmierci Ludwika Elżbieta zerwała wszelkie kontakty z Habsburgami w sprawie małżestwa Jadwigi z Wilhelmem. Minął rok 1383, w którym miano złożyć posag i wiano dla narzeczonych, lecz w tej sprawie dwory budziński i wiedeński nie nawiązały żadnego porozumienia. Owszem, w deklaracji lipcowej Leopold obiecał złożyć dla Wilhelma wiano, nie żądając od królowej posagu, bo bogactwem Jadwigi była polska korona, lecz to było w sprawie połączenia dzieci z naddunajskich stolic ponowne nawiązanie rozmów.

46 O dacie urodzenia Jadwigi pisali: J. Dąbrowski, Królowa Jadwiga; tenże, Ostatnie lata..., 16; Maciejewska, 171; H. Quillus, Königin Hedvig von Polen, 127. Szeroko tę sprawę omówiła A. Strzelecka w odczycie w KIK, 14 II 1974. S. Thomae Aquin., Summa Theol., supplementum partis III tiae, qu. XLIII, a. 7: „Si aliqui iuxta aetatem pubertatis, quamvis ante eam, contrahant per verba de praesenti, reputatur inter eos matrimonium esse. Ergo pari ratione ante septennium, dummodo sit propinquum, contrahant per verba de futuro, reputabuntur inter eos esse sponsalia. Ad septimum dicendum, quod in sponsalibus etiam similiter ei appropinquant contrahentes ad tempus septennii contractus sponsalium habet robur, quia secundum Philosophum quod parum deest, quasi nihil deesse videtur. Haec autem propinquitas a quibusdam determinatur tempus sex mensium. Sed melius est quod determinetur secundum conditionem contrahentium, quia in quibusdam magis acceleratur usus rationis quam in aliis". 
Rada królewska potraktowała wspomnianą deklarację jako niewłaściwe wtrącanie się przez stronę austriacką w sprawy polskie. Od dwóch lat bowiem wiadomo było Habsburgom, że naród polski nie życzy sobie Wilhelma jako męża Jadwigi. Wymuszenie na królowej-matce zgody na natychmiastowe dopełnienie małżenstwa było nie tylko sprzeczne $\mathrm{z}$ interesami państwa polskiego, ale zupełnie nie na czasie, skoro posłowie polscy w tym samym terminie zawierali układ ślubny z Jagiełłą; układ ten przecież wiązał tak przedstawicieli narodu polskiego, jak i samą Jadwigę. Zaistniała paradoksalna sytuacja. W tych samych dniach wysłannicy królowej Elżbiety Stefan proboszcz czanadzki i Władysław kasztelan z Potoku węgierskiego składali w Krewie deklarację o zgodzie królowej-matki na małżeństwo z Jagiełłą i równocześnie w Krakowie Opolczyk przedstawiał zgodę królowej węgierskiej na dopełnienie małżeństwa $z$ Wilhelmem. Panowie krakowscy byli wytrawnymi politykami. Podobnie jak umieli odsunąć od ręki Jadwigi Ziemowita mazowieckiego, nie ulękli się Zygmunta Luksemburczyka, który im się po śmierci Ludwika narzucał na króla, chcąc Polskę złączyć z tronem węgierskim i zamknęli przed nim bramy Krakowa, a gdy tenże Luksemburg chciał być gubernatorem Polski z ramienia Elżbiety Bośniaczki potrafili go zmusić do opuszczenia granic kraju, tak i teraz nie pozwolili się wywieść w pole księciu Władysławowi Opolczykowi. Na widok strojnego orszaku Wilhelma, wiozącego zapewne dary dla Jadwigi w złocie i klejnotach, pan grodu wawelskiego i pierwszy dostojnik Królestwa, kasztelan krakowski Dobiesław z Kurozwęk polecił zamknąć bramy zamkowe ${ }^{47}$. Na próżno Wilhelm stał przed swą krakowską Canossą. Musiał się wycofać i zapewne znalazł tymczasową gościnę - jak chce prawdopodobna tradycja, którą zapisał Długosz - w dworcu Gniewosza z Dalewic przy ulicy Legackiej ${ }^{48}$. Nie ulega wątpliwości, że tu otrzymał polecenie natychmiastowego wyjazdu z Krakowa i Polski ${ }^{49}$.

47 „Dobeslao autem de Kuroszwanky castellano Cracoviensi, qui et ipse arci Cracoviensi et summae rerum praeerat, Wilhelmo Austriae Duci ad castrum Cracoviense negante prohibenteque ingressum [...]". Długosz, 457.

4h A Strzelecka, Z przeszłości powięziennych gmachów św. Michała $w$ Krakowie, „Biuletyn Historii Sztuki” 1956, z. 2.

4:" O wypędzeniu Wilhelma z Krakowa i Polski jednogłośnie świadczą współczesne źródła austriackie, które w sprawach tamtejszej dynastii były chyba najlepiej poinformowane. Wiarygodność ich jest tym większa, że opowiadają o fakcie który nie był sukcesem książąt Austrii. Wiedeńskie Roczniki (Wiener Annalen von 1348-1404 (WienAn), ed. J. Seemüller, Monumenta Germaniae Historica (MGH) Deutsche Chroniken, VI, 234) notują pod rokiem 1386, że Wilhelm został wygnany z Krakowa, a poganin z Litwy zabrał mu żonę. Leżący blisko Wiednia klasztor W Klosterneuburg posiada kontynuację roczników z . 1307-1455 (Continuatio Claustroburgensis, ed. W. Wattenbach, MGH SS, IX, Leipzig 1925, tzw. Kronika Paltrama (ConClaustr), 736), w których jest zapisana wiadomość, przejęta następnie przez Długosza (457), że gdy Wilhelm miał pierwszej nocy po przyjeździe spać z królową, baronowie i potężni panowie polscy chcieli go zarżnąć (iugulare), ale królowa go zawezasu ostrzegła: Withelm uciekł potajemnie i więcej już do Krakowa nie po- 
Wieść o przybyciu księcia austriackiego szybko się rozniosła $\mathrm{w}$ krakowskim środowisku stołecznym, które już pożegnało się z myślą o panowaniu Habsburga na Wawelu, a oczekiwało przyjazdu Jagiełły 50 i wywołała niemałe zdziwienie. Nie wiedziano oczywiście o budzińskiej deklaracji i przyjazd Wilhelma przypisywano wezwaniu go przez Jadwigę. Ułożono barwną opowieść, że młoda królowa kochała szlachetnego młodzieńca ${ }^{51}$, a brzydziła się „,barbarzyńskim” Litwinem ${ }^{52}$, którego jej dawano za męża. J. Długosz pozbierał te opowiadania i umieścił je w Hi-

wrócił. W leżącym nad Dunajem na zachód od Wiednia klasztorze Melk annalista zapisał, że w r. 1386 książę Wilhelm został wygnany z Krakowa (Annales Mellicenses, Continuatio Mellicensis 1124-1564, ed. W. Wattenbach, MGH SS, IX, Leipzig 1925 (ConMelk), 514). W alpejskim opactwie w Salzburgu pisał zakonnik, że WiIhelm został wygnany z Krakowa (Continuatio Monachorum Sancti Petri 1375-1398, ed. W. Wattenbach, MGH IX, 840). Tak więc i ośrodek wiedeński i trzy wspólcześnie piszące austriackie skryptoria otrzymały zgodną informację, że Wilhelm został z Krakowa wyrzucony. Piszący później kartuz austriacki, który chciał przedstawić dzieje fundatora swego klasztoru w Gaming (Chronicon Alberti ducis Austriae, SRA II, Viennae 1743, 380) użala się nad Wilhelmem, że został wypędzony z Krakowa i przybył do Austrii, nie oglądając się za siebie. Wiadomość u Długosza $(456,459)$ o dłuższym pobycie Wilhelma w Krakowie, o ukrywaniu się w Eobzowie i w kominie domu Morsztynowskiego (róg ulic Sławkowskiej i Szczepańskiej), opatrzona zreszta epitetem: ,a nonnullis credebatur" i ,ferunt", co oznacza malo prawdopodobną pogłoskę, w świetle zapisów annałów i kronik austriackich nie posiada znamion prawdy historycznej.

50 Małżeństwo Jagiełły z Jadwigą już przy końcu roku 1374 tak się wydawało pewne, że Ziemowit IV mazowiecki w tym czasie złożył hołd przyszłemu królowi. Kuczyński, 233.

51 Miłość Jadwigi do Wilhelma podkreślały dworskie koła austriackie, by wykazać, że nie było powodu do zrywania zaręczyn zawartych w Hainburgu. Panna chłopca kochała i czuła się przy nim szczęśliwa. Dlatego wśród kronik europejskich przede wszystkim kroniki austriackie zaznaczały, że Jadwiga została wydana za Jagiełłę wbrew jej woli. Österreichische Chronik von den 95 Herreschaften, ed. J. Seemüller, MGH, VI, 205 (OÓsterChron) podaje: „Der selb haiden (Jagiełło) - nam frawn über irs herczen willen - mit dem willen irr vaigen muter". Kronikarz z Klosterneuburga (ConClaustr, 736 i 738) opowiada, że Wilhelm, którego panowie polscy chcieli zamordować, uszedł potajemnie i więcej nie wrócił, a polscy panowie wydali. Jadwigę wbrew jej woli za pewnego poganina, którego ukoronowali na króla. Ebendorfer, 814, powiada, że Jadwiga próbowała ucieczki z zamknięcia: ,sub arcta tenebatur custodia, ne fugam inire posset, quam et vicibus repetitis attentavit". Dietrich z Nieheim (Teodoryk $\mathrm{z}$ Niem), który byl abrewiatorem kancelarii papieskiej Urbana VI i stykal się z aktami procesu, jaki wytoczył w Rzymie Wilhelm, jest świadkiem, że Habsburg podawał w skardze fakt wyrzucenia go z Krakowa, mimo chęci wspomnianej królowej jego żony (De schismate omnium longissimo perniciosissimo libri tres, Norimbergae 1522, I, Ic, 58, s. 26). Księgę Nieheima posiadał nasz historyk Jan Długosz. Pod wpływem kronik austriackich Długosz przypisuje Jadwidze wielką miłość do Wilhelma i jej próby ucieczki (por. 457). Ta wielka miłość Jadwigi do W'ilhelma jest wątpliwa. Nie mogła się zrodzić w dziewczynie pięcioletniej, bo w tym wieku po raz ostatni stykała się z Wilhelmem; potem Jadwiga była wychowywana przez matkę w obcości do Habsburgów, a dwuletni pobyt w Krakowie zupełnie obraz Wilhelma od niej odsunął.

${ }_{52}$ Opowiadania o ,barbarzyńskości” Olgierdowicza były szerzone przez propagandę austriacką i krzyżacką. Kultura bizantyńska, która krzewiła się na ruskich dworach (matką Jagiełły była chrześcijańska księżniczka twerska Julianna) była wysoka, choć inna niż kultura francusko-włoska. Król w swym postępawariu podkreślał wyjątkowe stanowisko królowej, której książęta litewsko-ruscy składali hold i przysięgę lenną, Jadwiga zatwierdzała dokumenty Jagiełłowe. W ciągu dwóch lat oczekiwania na pełnoletność Jadwiga na swym dworze przyjmowała posłjw litewskich, miała okazj€̨ przyjrzeć się ruskiej kulturze. Kuczyński, 238-239. 
storii polskiej, lecz nie bardzo dawał im wiary, bo każdy fragment brukowych nowinek opatrywał nagłówkiem: ,a nonnullis credebatur”, ,fertur" itp. ${ }^{53}$

Wilhelm w krótkim czasie pożegnał Kraków. Nie było dla niego rzeczą dyplomatyczną wracać natychmiast do Wiednia, z którego wyjechał po polską koronę. Szybki powrót nad Dunaj wskazywałby Austriakom na jego niechwalebny odwrót zarówno od progów narzeczonej, jak i Królestwa Polskiego. Może pojechał $\mathrm{w}$ świat szukać rady i pomocy. Lecz ani Krzyżacy, którzy nie posiadali odpowiedniej siły, ani margrabia branderburski Zygmunt Luksemburg, który zrujnował się na wystawienie armii w celu zdobycia Marii Andegaweńskiej i musiał się wycofać, nie mogli mu ofiarować swego poparcia. W Polsce nie miał własnego stronnictwa, a Jadwiga, prawie mu nieznana, bo od sześciu lat jej nie widział, idąc za wymaganiami polskiej racji stanu wybrała innego narzeczonego.

Władysław Opolczyk i Gniewosz z Dalewic, którzy okazali pewną pomoc Wilhelmowi przy jego staraniach o pozyskanie Jadwigi, widząc jego sprawę zupełnie w Krakowie przegraną, przerzucili się szybko na stronę Jagiełły, któremu ofiarowali swoje usługi. Pierwszy $z$ nich upoważniał w imieniu Elżbiety węgierskiej posłów do preelekcji Jagiełły na króla polskiego i był chrzestnym ojcem wielkiego księcia litewskiego, a drugi stojąc wiernie przy boku Jagiełły, doszedł do licznych i znacznych urzędów państwowych.

\section{JADWIGA A FRANCISZKANIE}

Zakon św. Franciszka, powstały w Asyżu na ziemi włoskiej, znalazł serdeczne przyjęcie u książąt piastowskich. Oni budowali pierwsze w Polsce klasztory dla synów Biedaczyny umbryjskiego, a księżniczka polska, błogosławiona Salomea była pierwszą franciszkanką-klaryską w Polsce. Te przejawy piastowskiej życzliwości dla Braci Mniejszych zaniosła na dwór budziński wnuczka klaryski błog. Jolanty Elżbieta Łokietkówna, która się chętnie otaczała polskimi franciszkanami, a o jednym z nich, Andrzeju h. Jastrzębiec, wiemy, że był jej spowiednikiem. Obserwowała to na budzińskim dworze mała Jadwiga i była świadkiem, jak jej babkę zamiast w nekropoli królewskiej złożono na wieczny spoczynek w naddunajskim kościele sióstr Klarysek. Gdy przybyła do Krakowa najpierw zwróciła uwagę na tutejszych franciszkanów, wśród których byli także znani jej z węgierskiej ojczyzny bracia. Może klaryskom, które jej pradziad Władysław Łokietek osadził w podwawelskim kościele 
św. Andrzeja, zleçiła Jadwiga wykonanie racjonału jako votum koronacyjnego dla katedry krakowskiej.

Wieść o zamierzonym małżeństwie Jadwigi z władcą Litwy napełniła franciszkanów krakowskich zrozumiałą radością, bo do Polski miał być przyłączony kraj, który był terenem ich prac misjonarskich od czasów Giedymina: Wedle tradycji ziemię wileńską miała zrosić krew męczeńska synów św. Franciszka. Na powiązania Jadwigi z franciszkanami wskazuje fakt, że za jej staraniem pierwszym biskupem Wilna został członek tego zakonu, wspomniany wyżej Andrzej Jastrzębiec, dawny spowiednik królowej Elżbiety Łokietkówny, który położył wielkie zasługi koło rozszerzenia chrześcijaństwa na Litwie. Doprowadzenie przez 14-letnią Jadwigę do nominacji (1488) franciszkanina na pierwszego biskupa nawróconej Litwy jest dowodem wcześnie zaplanowanej przez Jadwigę akcji rozwoju Kościoła u świeżo pozyskanego dla chrześcijaństwa ludu.

Mieszczanie stolicy zauważyli żywą sympatię, jaką królowa okazywała ubogim braciom. I gdy później opowiadano o przyjeździe do Krakowa Wilhelma, któremu zamknięto bramy do poślubionej sobie w dzieciństwie królowej i poczęła się snuć romantyczna opowieść o ich miłości, wówczas włączono do niej oddanych Jadwidze franciszkanów, czyniąc ich pośrednikami między królową a Wilhelmem, co z pewnością nie miało miejsca.

Były to czasy, które usposabiały do słuchania opowiadań o nieszczęśliwych, zamkniętych $\mathrm{w}$ zaczarowanych zamkach księżniczkach, na których ratunek spieszą, mimo lwów i wielkoludów utrudniających do nich dostęp, ofiarni rycerze, jak Galwanus i Lancelot, towarzysze króla Artusa 54. Rzewnie wspominano spotkanie należących do kręgu arturiańskiego kochanków Tristana i Izoldę ${ }^{55}$ lub przeżywających tragiczne chwile Pyrama i Tysbe ${ }^{56}$. O popularności tych historyjek świadczą płaskorzeźbione sceny na ścianach skrzyneczki z kości słoniowej, którą królowa Jadwiga miała przywieźć do Polski. Do tego zespołu przybyła nowa opowieść o królowej Jadwidze, zamkniętej w niedostępnym zamku, nieszczęśliwej, bo zmuszanej do wyjścia za dzikiego i nieokrzesanego mieszkańca puszcz litewskich, księcia Jagiełłę i dlatego nie dziw, że chętnie zbiegała z góry zamkowej, do której kochankowi była droga zamknięta, by wpaść w ramiona umiłowanego Wilhelma i pląsać z nim w klasztornej sali (chorearum solatia).

Cała ta anegdota, którą gdzieś posłyszawszy Długosz, jedyny wśród kronikarzy zapisał ${ }^{57}$, nie zasługuje na wiarę z następujących względów:

${ }^{54}$ E. K. Chambers, Arthur of Britain, London 1927; E. Faral, La légende Arthurienne, 3 tomy, Paris 1929.

55 Golther, Tristan und Isolde in Dichtungen des Mittelalters und Neuzeit, Leipzig 1907: F. Ranke, Tristan und Isolde, München 1925.

56 Publius Ovidius Naso, Metamorphoses, IV, 55.

57 Długosz, 457. 
Wilhelm nie przyjechał do Krakowa, aby się bawić z Jadwigą w klasztornym ukryciu, lecz żeby dopełnić małżeństwa w dniu, w którym Jadwiga rozpoczynała sześciomiesięczny okres przed uzyskaniem pełnoletności (15 VIII 1385) i wyciągnąc z tego faktu odpowiednie korzyści polityczne; po wtóre panowie polscy nie mogli pozwolić na to, by w tym samym czasie, kiedy przedstawiciele i posłowie królowej matki podpisywali ukı̊ad ślubny z Jagiełłą, Jadwiga wyciągała rękę ku dawnemu narzeczonemu i narażała polską politykę na szwank; po trzecie nie jest rzeczą pewną, czy Jadwiga była w Wilhelmie zakochana, za to dużo serca okazywała panom krakowskim, którzy jej w żadnej trudnej sytuacji nie opuścili, a wśród nich sędziwy kasztelan krakowski Dobiesław z Kurozwęk kochał ją jak córkę i strzegł jak oka w głowie; po czwarte panowie wawelscy mogli mieć obawę porwania panny, np. do odległych o trzy mile od Krakowa Dalewic i urządzenia tam ,,pokładzin” w myśl aktu z dnia 29 lipca tegoż roku. Politycy polscy chyba dobrze pamiętali, jak w poprzednim roku około 8 maja, na pierwszą zapowiedź przyjazdu Jadwigi silny zastęp rycerski, wśród którego był ukryty książę Ziemowit IV, przygotował plan porwania królewny i zmuszenia jej do zrękowin $\mathrm{z}$ panem Mazowsza płockiego i wspólnej koronacji. Podobnego atentatu można się było spodziewać od drugiego pretendenta do tronu polskiego, z pewnością otoczonego oddziałem rycerstwa śląskiego, przyprowadzonego przez Opolczyka.

Z powyższych powodów nie można uznać Długoszowej fabuły za opowieść o autentycznym wydarzeniu. Plotka o pląsach królowej Jadwigi w refektarzu franciszkańskim musi być odłożona do lamusa ciekawych dykteryjek na tematy historyczne ${ }^{58}$.

58 Opowieść o spotkaniu się w Krakowie Wilhelma z Jadwigą nie była pozbawiona znaczenia. Slub hainburski, zawarty przed 7 rokiem życia, nie miał dla Jadwigi żadnej ważności, nawet jako zaręczyny. Już prawo rzymskie mówiło: ,Sponsalia sicut nuptiae consensu contrahentium fiunt; et ideo sicut in nuptiis ita sponsalibus filiam familiae consentire oportet". Dig XXIII, c. I, 11. A. Ulpianus wyjaśnia: „Sufficit nudus consensus ad constituenda sponsalia”. Tamże, 4. Prawo kościelne dokładniej tę sprawę określa: „Aetas septem annorum requiritur ad sponsalia celebranda: quia ad promissionem requiritur usus rationis". Bonacina I, s. 239 n. $1-1$, s. 240 n. 6 . Wykład zaś o zrękowinach małoletnich brzmi: „Parentes seu tutores, curatores et consanguinei curam gerentes infantum, possunt, urgente gravi necessitate, pro filiis contrahere sponsalia ante septennium. Ut tamen sint valida, requiritur postea consensus expressus vel tacitus filiorum, postquam pervenerint ad usum rationis", tamże I, s. 240 n. 8. Do tego, aby zaręczyny dzieci nie liczących 7 lat życia stały się ważne i obowiązujące w sumieniu, potrzeba było, ażeby te dzieci po skończeniu siódmego roku życia potwierdziły zaręczyny, dały na nie zgodę, choćby nawet ten konsens był „tacitus, nudus”. Spotkanie Jadwigi, liczącej lat $11 \mathrm{z}$ Wilhelmem w klasztorze franciszkańskim na sposób narzeczeński uczyniłoby zrękowiny zawarte $\mathrm{w}$ dzieciństwie ipso facto ważne. A jednak Jadwiga nie uważała ich za ważne, o czym świadczy ta dziwna - zdawałoby się - klauzula, włączona do tekstu odwołania zaręczyn: ,si qua fuerunt”. Jadwiga nie powątpiewa tu $w$ zajście faktu zaręczyn, bo przecież na pewno je doskonale pamiętała, lecz wyraża wątpliwość w ważność tych zaręczyn, co mogło mieć tylko wtedy miejsce, gdy zaręczyny nie były potwierdzone przez nią po siódmym roku życia. 


\section{POWRÓT POSŁÓW $\mathrm{z}$ KREWA, 23 VIII 1385}

Krótki incydent $\mathrm{z}$ Wilhelmem, którego panowie piastujący władzę na Wawelu usunęli z Krakowa i z Polski, tylko na kilka dni odwrócil myśl Jadwigi od najważniejszych dla niej spraw życiowych, jakim było ostateczne ułożenie jej związku małżeńskiego $\mathrm{z}$ wielkim księciem Litwy i przyszłość Królestwa Polskiego uzależniona od związku Polski z wielkimi obszarami na wschodzie. Wolno nam przypuszczać, że niecierpliwie oczekiwała powrotu posłów z Krewa. Jakoż w dziewiątym dniu po podpisaniu umowy ślubnej 59 przez Jagiełłę, zjawili się posłowie w samą wigilię św. Bartłomieja (23 VIII 1385), przynosząc radosną dla Jadwigi wieść o pomyślnym wyniku układów. Wówczas Jadwiga, aby wyrazić swe zadowolenie $\mathrm{z}$ pozytywnych rezultatów rokowan, poleciła uczcić dzień, w którym otrzymała tę wiadomość, zwolnieniem wszystkich przestępców zatrzymanych $\mathrm{w}$ więzieniu miejskim. Pisarz krakowski uwiecznił ten fakt w Liber Proscriptionum:

,Notandum est, quod in vigilia sancti Bartholomaei, post nuptiarum domine reginae consummationem, commissum est et rogatum fuit per eandem dominam, ut captivi omnes, qui protunc in civitatis detentione habentur, deberent liberari" 60 .

Było zwyczajem królowej Jadwigi, że folgując dobroci swego serca, korzystała z różnych okazji, aby dla uczczenia ważnych wydarzeń wno-

Ta formuła rewokacji wskazuje na to, że spotkania z Wilhelmem po jego przyjeździe do Krakowa nie było. Habsburgowie dążyli do dopełnienia małżeństwa Wilhelma $\mathrm{z}$ Jadwigą $w$ możliwie najwcześniejszym terminie (początek szóstego miesiąca przed pełnoletnością Jadwigi), bo się obawiali rewokacji zaręczyn. Zrozumieli bowiem, że wtedy ich sytuacja wobec prawa kościelnego będzie przegrana. Po odwołaniu zaręczyn Habsburgom pozostało tylko stworzyć mistyfikację wcześniejszego dopełnienia małżeństwa Wilhelma z Jadwigą.

${ }_{59}$ Podpisanie nastąpiło 14 VIII 1385 r. Posłowie królowej węgierskiej Elżbiety, Stefan, proboszcz czanadzki i Władysław de Kaza, kasztelan Potoka węgierskiego wraz z trzema posłami polskimi Włodkiem z Charbinowic, Mikołajem Bogorią i Krystynem z Ostrowa, którzy również otrzymali upoważnienie od Bośniaczki, przedstawili w Krewie warunki, pod jakimi królowa matka Elżbieta i panowie polscy godzą się na oddanie ręki polskiej królowej Jadwigi wielkiemu księciu litewskiemu. Warunki te, zwane legationes, Jagiełło i książęta litewscy Skirgiełło, Korybut, Lingwen, bracia wielkiego księcia i Witold, kuzyn, występujący w imieniu pozostałych braci, obecnych i nieobecnych, przyjęli i zatwierdzili, przywieszając do dokumentu, nazwanego memoriale dicendorum, swe pieczęcie (Akta unii, nr 1, s. 1-3). Dokument krewski, zawierający zgodę matki, społeczności rycerskiej Polski i książąt litewskich na ślub Jadwigi z Jagiełłą i wymieniający warunki, pod którymi ten ślub może być udzielony, został najpierw przedstawiony w Krakowie Jadwidze, jak słusznie na odwrocie pergaminu zapisali w późniejszych wiekach notariusze kapituły: „Litterae Jagelonis, magni ducis Lithvuaniae pro regina Poluniae Hedvigi, quam sibi in uxorem copulari postulat". Jadwiga przekazała dyplom związany z przygotowaniami do ślubu, tym, którzy mieli jej ślubu udzielić, i stąd dokument ten znalazł się w Archiwum Kapituły Krakowskiej. H. Paszkiewicz, O genezie $i$ wartości Krewa, Warszawa 1938; tenże, W sprawie inkorporacji Litwy do Polski w 80-tych latach XIV wieku, Warszawa 1938; S. Zajączkowski. W sprawie badań nad dziejami stosunków polsko-litewskich za Jagiellonów, w: Studia Historica w 35-lecie pracy naukowej $H$. Łowmiańskiego, Warszawa 1958, 199-217.

${ }_{60}$ Najstarsze księgi rachunkowe miasta Krakowa, MMedAev II, 63. 
sié prośbę do zarządu miasta o wybawienie więźniów ${ }^{61}$. Specjalne i silne podkreślenie tenoru zarządzenia królowej przez pisarza: „commissum est et rogatum fuit" wskazuje na to, że królowej bardzo zależało na zamanifestowaniu doniosłego znaczenia wiadomości o wyniku rozmów w Krewie.

Dotychczas wszyscy historycy życia królowej Jadwigi tłumaczyli nuptiarum consummatio jako rzeczywiste lub mistyfikowane dopełnienie malżeństwa przez Wilhelma, błędnie uważając, że consummatio (rzekomo od consumere) znaczy tyle, co spożycie, użycie małżeństwa, to jest copula carnalis. Tymczasem consummatio wywodzi się od con + summum, czyli ma znaczenie doprowadzenia jakiejś sprawy do końca. W tym znaczeniu mówi się: „consummatio rerum, consummatio mundi” - koniec świata. Wprawdzie $\mathrm{w}$ małżeństwie, gdzie istotą jest consensus matrimonialis, carnalis commixtio, która według św. Tomasza $\mathrm{z}$ Akwinu (Summa Theol., Suppl. partis III, qu. XLII, a. 4) należy do integralności małżeństwa jako drugi jego element składowy, zasługuje na nazwę consummationis, to jednak słowo consummatio $\mathrm{z}$ Liber Proscriptionum posiada inne znaczenie. W tekście notariusza krakowskiego jest mowa o dokończeniu negocjacji ślubnych z Jagiełłą: nuptiarum, a nie „matrimonii" consummatio. To właśnie było powodem radości w Krakowie, której towarzyszyło zwolnienie wszystkich więźniów, zatrzymywanych w areszcie miejskim. Ten tekst również potwierdza niewątpliwą aprobatę ze strony Jadwigi dla małżeństwa z Jagiełłą. Na podstawie zachoWania się Jadwigi po otrzymaniu wiadomości o tym, że została narzeczoną księcia Litwy, możemy wnioskować, że nie tylko panowie polscy, ale i ona sama była kowalem swego małżeńskiego szczęścia.

\section{PRZYJAZD JAGIEEEY DO KRAKOWA JEGO CHRZEST, SLUB Z JADWIGĄ I KORONACJA}

Naprzeciw Jagiełły, który wybierał się do Polski, wyjechali posłowie Włodko z Charbinowic, starosta lubelski, Piotr Szafraniec, podezaszy krakowski, Mikołaj Bogoria, kasztelan zawichojski i Krystyn z Ostrowa, dzierżawca kazimierski. Otrzymali oni upoważnienia (litterae credentiales) od Władysława Opolczyka, plenipotenta Elżbiety Węgierskiej, co eznaczało ipso facto jej rezygnację ${ }^{62} \mathrm{z}$ tytułu królowej polskiej oraz øł możnowładców krakowskich jako przedstawicieli ogółu rycerstwa; pis-

"1 Jadwiga po swej koronacji ulaskawila 10 XI 1384 kilku więźniów (Najstarsze księgi, 60), a później, biorąc w dniu 1 VI 1385 udzial w procesji Bożego Ciała uprosiła wolność dla kilku więźniôw miejskich (tamże, 61).

6: Wiadoma jest rzeczą, ile Polske kosztowało zatrzymywanie przez czeskich Luksemburczyków tytułu króla polskiego za czasów Kazimierza Wielkiego. Rezygracja Elżbiety zabezpieczyła Polskę przed tego rodzaju trudnościami. Mimo to Elíbieta zachowala jeszcze pretensje do Rusi Czerwonej. 
ma te przedłożyli Jagielle w Wołkowysku. Układ w Krewie był tylko intercyzą ślubną, wykazującą, jakie warunki miał wypełnić wielki książę litewski, aby otrzymać rękę Jadwigi; w odpowiedzi na jego zobowiązania społeczność polska dała mu koronę Królestwa Polskiego i Jadwigę, naturalną panią kraju, za żonę ${ }^{63}$. Dokument ma formę wzajemnej kondonacji, dlatego korona i Jadwiga są przedmiotem kontraktu; trzeba jednak zauważyć, że Jadwiga nie była tylko biernym obiektem układu, skoro przedtem wyraziła swą zgodę na to małżeństwo. Posłowie dokonali dnia 11 stycznia 1386 w Wołkowysku preelekcji Jagiełły na króla polskiego i ustalili, że wielki książę litewski przybędzie dnia 2 lutego na .zjazd szlachty w Lublinie. Ponieważ miał przybyć w granice Polski tylko w otoczeniu książąt i niektórych bojarów, bez żadnej siły zbrojnej, dlatego posłowie udzielili jemu, jak i jego wysłańcom, glejtu bezpieczeństwa ${ }^{64}$.

Przejeżdżając ziemię polską w drodze do stolicy, Jagiełło zatrzymał się dwa razy na dłuższy pobyt w Lublinie i Sandomierzu. Posłowie, którzy dokonali jego preelekcji w Wołkowysku stale mu towarzyszyli i byli świadkami jego formalnej elekcji w Lublinie. Jagiełło spotkał się wówczas $\mathrm{z}$ wielu magnatami polskimi, szczególnie miłe mu było powitanie przez Spytka z Melsztyna, jego największego zwolennika. Tymczasem w Krakowie przygotowywał się wielki zjazd rycerstwa w celu powitania nowego króla.

Gdy Jagiełło zbliżył się do Sandomierza, Jadwiga wysłała na powitanie księcia swego osobistego posła (miles aulae) Zawiszę Czerwonego z Oleśnicy. Było to formą zwykłej uprzejmości wobec zbliżającego się: do: stolicy narzeczonego ${ }^{65}$. Bawiąc w Sandomierzu elekt polski wysłał podskarbiego Królestwa Polskiego Dymitra z Goraja do wielkiego mistrza Zakonu Krzyżackiego Konrada Zollnera von Rottenstein $\mathrm{z}$ prośbą, by przyjął obowiązki jego ojca chrzestnego, wziął udżiał w jego uroczystości ślubnej i koronacji królewskiej. Krzyżacy, dla których chrzest wielkiego księcia litewskiego w Krakowie, a nie w Malborku, jak było projektowane, był wielką polityczną klęską, wzgardzili zaproszeniem, uważając je za naigrawanie się z nich. Zamiast udać się na wesele Jägiełły wielki mistrz zaczął organizować przy pomocy zbiegłego z ojczyz: ny brata Jagiełłowego Andrzeja najazd na Litwę, odparty szczęśliwie:

63 „Inclitissimam Hedvigem et praeclaram reginam Poloniae naturalem in coniugem legitimam conditione matrimoniali dedimus, condonamus, conferimus et contulimus copulandam". Akta unii, $\mathrm{nr} 2, \mathrm{~s} .3-4$.

64 Tamże, 4.

65 Zlośliwi, niechętni Jagielle, ten akt kurtuazyjny Jadwigi wykorzystali w celu wyśmiewania się z Jagiełly: Jadwiga miała.Zawiszę wysłać na spotkanie Jagiełły, by obejrzał potwora litewskiego. Plotka jest nieprawdopodobna, bo Jadwiga już dawno miała $w$ swym otoczeniu ludzi, którzy znali Jagiełłę: Poza tym. Zawisza Czerwony z pewnością był zwolennikiem Jagiełły. Długosz, 458. 
przez Skirgiełłę, najbliższego Jagielle brata i przez jego kuzyna Witolda Kiejstutowicza.

Z Sandomierza Jagiełło jechał otoczony nie tylko Litwinami i Rusinami, ale i coraz większą liczbą polskich panów i rycerzy i odbył wspaniały wjazd do Krakowa. Zaprowadzony na zamek krakowski powitał w komnacie Jadwigę przyjmującą go w obecności matron i panien swego dworu. Oczarowany urodą i wdziękiem swej młodziutkiej narzeczonej (w tym czasie nie miała równej sobie pod względem piękności) ${ }^{66}$, nazajutrz przesłal przez Witolda, Borysa i Swidrygiełłę dary w złocie, srebrze, drogich kamieniach i szatach.

W następnych dniach wielki książę, jego bracia i bojarzy byli pouczani pokrótce o prawdach wiary chrześcijańskiej; chrzest ich odbył się dnia 15 lutego $1386 \mathrm{w}$ kościele katedralnym krakowskim, a udzielił go Bodzanta, arcybiskup gnieźnieński, w obecnosci Jana Radlicy, biskupa krakowskiego. W miejsce pogańskich przyjęli Litwini imiona chrześcijańskie: Jagielle zostało nadane dynastyczne imię Eokietka Władysław ${ }^{67}$, Korygiełło otrzymał imię Kazimierza, Swidrygiełło Bolesława. Inni książęta, bracia Jagiełły, ochrzczeni w obrządku greckim, nie dali się nakłonić do przyjęcia uzupełnienia ceremonii.

Przy chrzcie Jagiełły w roli ojca chrzestnego wystąpił Władysław Opolczyk, który niejako reprezentował węgierską dynastię, przedstawiając jej interesy na dworze krakowskim, zaś chrzestną matką była Jadwiga z Melsztyńskich Pilecka, wdowa po Ottonie Toporczyku, wojewodzie sandomierskim, zwana Ottonissą. Była ona siostrą wojewody krakowskiego, Spytka z Melsztyna, który wraz z drugim Leliwitą, kuzynem Janem Tarnowskim był naczelnym promotorem unii Polski z Litwą. Sama Ottonissa, zaangażowana w sprawę unii i doradczyni Jadwigi, bywa nazywana „chrzestną matką unii”. Jagiełłó bardzo ją cenił, a jej córkę wziął za trzecią swą zonę.

Dnia 18 lutego 1386 odbył się ślub Jagiełly z Jadwigą. Udzielił go arcybiskup gnieźnieński Bodzanta w asystencji bpa Jana Radlicy. Przed ślubem Jadwiga złożyła deklarację, o której Długosz milczy, rozwodząc się natomiast nad rzekomymi skrupułami Jadwigi 68 odnośnie tego ślubu.

66 „Cuius speciem et decorem et contemplans et admirans (neque enim pro ea tempestate in orbe universo parem in pulchritudine aestimata est habuisse)". Długosz, 459.

67 Jagiełło otrzymał na chrzcie nomen gloriosum, czyli imię królewskie. Por. Poczet królów polskich, MPH III, 295.

6s J. Długosz zapisał wiadomość o rzekomych skrupułach Jadwigi pod wpływem propagandy austriackiej i książek humanisty Eneasza Sylwiusza Piccolomini. Sluby małoletnich dzieci były instrumentem polityki dynastycznej i często się nimi posługiwano, dlatego nie mogły powodować skrupułów u Jadwigi. Jej starsza siostra w r. 1385 dwa razy była zaślubiona, w czerwcu z królewiczem francuskim Ludwikiem Orleańskim per procuram, co nie przeszkadzało, że w sierpniu zawarła 
O tej deklaracji tak pisał współcześnie żyjący duchowny katedry krakowskiej przy nocie ślubnej Jagiełły z Jadwigą.

„Et licet predicta Hedvigis, ut asserebatur, in annis puerilibus fuisset Wylhelmo duci de Austria per parentes desponsata, tamen tunc existens in annis maturitatis publice in ecclesia predicta ipsa sponsalia, si qua fuerunt, irritavit et revocavit" 69.

Jadwiga ukończywszy lat $12^{70}$ (które stanowiły wówczas anni maturitatis czyli lata dojrzałości, tak zwane lata sprawne do zawarcia małżeństwa), unieważniła wszystkie umowy zawarte $w$ sprawie jej zrękowin przez rodziców $(1375,1380)$ i ślub hainburski (1378), który w istocie $z$ powodu małoletności Jadwigi był tylko specjalną ceremonią narzeczeństwa ${ }^{71}$. Zwraca uwagę zastrzeżenie, wyrażone przez Jadwigę w czasie odwołania sponsaliów z Wilhelmem ,si qua fuerunt" (poprawnie winno być „si quae fuissent”) czyli „,jeżeli jakowe sponsalia miały miejsce", które oznaczało, że przygotowująca się do ślubu panna młoda nie uważała zaręczyn dokonanych przez rodziców za ważne i obowiązujące ją w sumieniu. Nie wątpiła w same fakty, bo $z$ pewnością dobrze pamiętała ślub hainburski, w którym jako czteroletnia dziewczynka na żądanie rodziców była zmuszona wziąć udział, ale nie uznawała jego siły obowiązywania $\mathrm{w}$ obecnym stanie. W tekście zapiski kalendarzowej wyrażnie jest podkreślone: „per parentes desponsata” to znaczy że sama Jadwiga $\mathrm{w}$ sprawie narzeczeństwa $\mathrm{z}$ Wilhelmem nie dokonała żadnego aktu, przez który by rodzicielskie umowy dobrowolnie i świadomie,

sponsalia z Zygmuntem Luksemburgiem. Karol IV Luksemburg cztery razy żenil małoletniego Wacława IV. Nie mogło być u Jadwigi skrupułów także z tego powodu, że nie uważała ślubów za ważne, a świadczą o tym słowa: „Si qua fuerunt. Non tenentur tamen filii consentire in sponsalia a parentibus vel curatoribus contracta, quia in iis, quae ad statum matrimonii spectant, filii, per se loquendo, non tenentur parentibus oboedire". Bonacina I, s. 240, nr 9, s. 134.

6 Kalendarz krakowski, MPH VI, 659.

7t „Ad validitatem matrimonii, iure ecclesiastico, requiritur in masculo aetas 14 annorum, et in femina 12, nisi malitia supplet aetatem, id est potentia generandi, et sufficiens discretio ad se obligandum. Sufficit autem illam aetatem esse moraliter completam". Bonacina I, s. $240 \mathrm{nr} 10$ i s. $241 \mathrm{nr}$ 11. Prawo rzymskie domagało się skończenia 12 lat przez nupturientkę z taką siłą, że malżeństwo zawarte przez pannę wcześniej stawało się ważne dopiero wówczas, gdy zaślubiona skonczyla 12 lat. "Minorem annis duodecim nuptam, tune legitimam uxorem fore, cum apud virum explesset duodecim annos". Kodeks Justyniana, Dig. XXII, c. II, 4.

"1 ,Sponsalia dissolvi possunt propter defectum aetatis impuberis: ius enim concedit, ut filii possint statim adepti pubertatem, resilire a sponsalibus celebratis, dum essent impuberes. Pubertatem autem adeptus, nisi statim resiliat a sponsalibus, non potest postea resilire, cum enim sponsalia ab initio essent manent valida et irrevocabiliá, nisi statim post pubertatem revocentur". Bonacina I, s. 243 $\mathrm{nr}$ 1. "Reclamatio ad sponsalia dirimenda fieri debet apud Episcopum vel eius Vicarium, vel ipsis deficientibus, apud personas honestas; hoc tamen videtur tantummodo necessarium in foro externo, ut iudex ferat sententiam pro sponsalibus dirimendis; quippe reclamatio requiritur in foro externo, ne videantur sponsalia prius facta ratificari". To ,statim" określano na 3 dni (triduum) po dojsciu do pelnoletności. Tamże, I. s. $244 \mathrm{nr} 5$. 
wzajemnie $z$ Wilhelmem (mutuo consensu) potwierdziła. A przecież tej rewokacji przysłuchiwał się Władysław Opolczyk, który na zlecenie Habsburgów miał doprowadzić Wilhelma do królowej. Gdyby się oboje w czasie bytności Wilhelma w Krakowie spotkali w sposób narzeczeński, np. w refektarzu franciszkańskim, Jadwiga nie mogłaby powiedzieć „,per parentes desponsata" bo sponsio byłaby wówczas dokonana przez nią samą w takim wieku, kiedy mogła działać świadomie i dobrowolnie.

Z chwilą zawarcia ślubu z Jagiełłą Jadwiga została wielką księżną litewską, panią Żmudzi i Rusi.

Do koronacji Jagiełły przystąpiono dnia 4 marca $1386 \mathrm{r}$. Wobec licznie zebranego ludu przyszedł Jagiełło w otoczeniu książąt i rycerstwa do krakowskiej katedry na Wawelu. Koronę na głowę Jagiełły nałożył arcybiskup Bodzanta w obecności królowej Jadwigi, w towarzystwie biskupów Jana Radlicy krakowskiego i Dobrogosta poznańskiego. Król miał wtedy lat 36, Jadwiga 12 .

\section{WROGA PROPAGANDA AUSTRIACKO-KRZYŻACKA ZWRÓCONA PRZECIW JADWIDZE I JAGIELLE}

Przybycie Wilhelma do Krakowa, który może po dwóch lub trzech dniach wyjechał ze stolicy, nie wywarlo na Jadwidze zbyt silnego wrażenia. Myśli jej były zajęte bliskim związkiem małżeńskim $\mathrm{z}$ wielkim księciem litewskim.

Jednak fakt przyjazdu Wilhelma i nadana temu tendencyjna wymowa została przez historiografów, kronikarzy i annalistów rozdmuchana do niebywałych rozmiarów. Dużo kart w swej Historii polskiej poświęca tej sprawie Długosz, notując plotki krakowskie i różne obce przekazy. Ze szczególniejszą złośliwością uderzają w postać Jadwigi, a potem w jej męża Jagiełłę, kroniki i roczniki austriackie i krzyżackie.

Gdzie szukać genezy tej całej kampanii fałszerstw, która z taką siłą uderzyła na polską parę królewską z terytorium austriackiego i ze skryptoriów Zakonu?

Wyjaśnienia tego faktu szukać trzeba na dworze wiedeńskim. Piętnastoletni książę Wilhelm, przybywszy do Wiednia, nie mógł głosić, że go w Krakowie w ogóle nie przyjęto, nie mógł się przyznawać, że Jadwiga nim się nie zainteresowała, że Habsburg nie wytrzymał konkurencji z "Saracenem” litewskim, i że nie ma żadnych praw do tak długo oczekiwanego królestwa związanego z ręką Jadwigi.

Przeglądnąwszy wszystkie wiadomości zawarte w ówczesnych lub niewiele późniejszych źródłach austriackich, możemy stwierdzić, że dwór wiedeński utworzył na temat Wilhelma i Jadwigi cztery fikcje, które 
szeroko rozgłoszono, a oddaleni od Polski kronikarze austriaccy zapewne w dobrej wierze spisywali je na pergaminie.

Pierwszą fikcją, którą w świetle źródeł polskich musimy uznać za zmyślenie, była rzekoma intronizacja Wilhelma w Krakowie. Książę austriacki miał przybyć z Węgier wraz ze swą młodocianą narzeczoną, a raczej żoną, bo zawarł z nią znany ślub w Hainburgu, a jako przyszły król polski odbył wjazd na zamek wawelski ${ }^{2}$. Zaraz po przyjeździe został ukoronowany ${ }^{73}$. Kłamliwe opowiadanie o intronizacji Wilhelma na Wawelu miało na celu wskazać, że młody książę rakuski zyskał niezaprzeczalne prawo do panowania nad Polską. W rzeczywistości Jadwiga - jak widzieliśmy - przyjechała do Polski w lecie 1384 przez Sącz, odprowadzana przez kardynała i arcybiskupa Esztergomu Dymitra, a Wilhelm po przyjeździe do Krakowa około 15 VIII 1385 r., został natychmiast odesłany do ojca i historia narodu polskiego bynajmniej nie zalicza go do serii koronowanych władców na tronie Piastów.

Drugim aktem rozwijających się zdarzeń na Wawelu według zmyślonej wersji wiedeńskiej miało być wesele Wilhelma z Jadwigą. W komnatach wawelskich odbyła się uczta godowa, po której nastąpiły albo były przygotowane pokładziny obojga młodych małżonków ${ }^{74}$. Rzekome do-

72 Kronika Austriacka (ÖsterChron) opowiada, że Wilhelm ,ward mit seiner prawt in das künigreich gen Krakau gefüret". Inna kronika o dziejach Austrii, napisana przez Ebendorfera, również twierdzi, że Wilhelm miał być zaprowadzony wraz z Jadwigą do Krakowa (s. 814). Teksty obu kronik austriàckich sprawiają wrażenie, że Wilhelm z Węgier $\mathrm{z}$ tamtejszą królową Jadwigą, która była jego narzeczoną, odbył uroczysty wjazd do stolicy Polski. Wśród polskich historyków S. M. Kuczyński wątpi, żeby taka uroczystość miała miejsce (250).

73 Wiadomość o królewskiej koronacji Wilhelma W Krakowie podają prawie wszystkie źródła austriackie. Roczniki wiedeńskie (WienAn, 234) zanotowały pod rokiem 1383: "Zu der selben Zeit ward herczog Wilhalb gechrönet zu Krakau". Leżące $w$ pobliżu Wiednia klasztory naddunajskie zapisały $w$ swoich annałach tę samą wiadomość. I tak klasztor w Klosterneuburgu (ConClaustr, 736) informuje, że Wilhelm był riegdyś królem Polski. Rocznikarz z Melku (ConMelk, 514) opowiadając o wypędzeniu Wilhelma z Krakowa w r. 1386 dodaje, że był królem. Także Ebendorfer (814) wyjaśnia w swojej Kronice austriackiej, że Wilhelm był przywiedziony do Krakowa po to, aby zostać ukoronowanym na króla Polski.

74 Współczesną wiadomość o dopełnieniu małżeństwa Jadwigi z Wilhelmem podaje Kronika austriacka (ÖsterChron, 204): Wilhelm uczynił wjazd z Jadwigą do Krakowa, ,do ward zwischen in die chanschaft volfüret, wan er bey ir offt ain nacht gelegen". Następne zapiski o dopełnieniu małżeństwa są dosyć późne, z poł. XV w. i pochodzą z Kronik Ebendorfera. Ebendorfer przyznaje, że Wilhelm małżeństwa dopełnił, lecz jeszcze w czasie weselnych uroczystości został przez Polaków zagrożony i musiał się ratować ucieczką, mimo że Jadwiga nie sama, lecz wraz z Królestwem Polskim była mu oddana. Zapisał to na początku 2 poł. XV w. w dziele Chronica regum Romanorum: „dum pluribus noctibus maritali affectu eam contrectasset, ut fateri solitus erat, infra nupciarum solemnia per Polonos capitur" (MIÖG III, ed. A. F. Pribram, Ergänzungsband 1890, 111-112). W jaki sposób Wilhelm ratował się ucieczką Ebendorfer przedstawia w Kronice austriackiej, w której powtarza, że Wilhelm ,ut saepe profiteri solitus erat, matrimonium inter eam (Hedvigem) et ducem est legitime consummatum". Po przyjeździe Jagiełły groziła Wilhelmowi śmierć, dlatego Jadwiga spuściła go w koszu na sznurze przez okno swej sypialni $i$ w ten sposób umożliwiła mu ucieczkę do Austrii (820). 
pełnienie małżeństwa miało dać Wilhelmowi, jako mężowi Jadwigi, naturalnej pani piastowskiej dziedzictwa, $\mathrm{z}$ którą żył $\mathrm{w}$ takim razie in martimonio rato et consummato, jeszcze większe prawo do panowania nad Polakami. Jest jednak jedna relacja $z$ klasztoru Kloserneuburg mówiąca o tym, że małżeństwo nie było dopełnione, bowiem w czasie uczty weselnej Wilhelm musiał uciekać, gdyż polscy panowie chcieli go zamordować ${ }^{75}$.

Jak doszło do tego, że mimo braku rzeczywistych pokładzin na Wawelu, Habsburgowie rozszerzyli pogłoskę (a za nimi czynili to Krzyżacy), że Jadwiga była cudzołożnicą, gdyż miała pierwszego męża Wilhelma? Duży wpływ na utworzenie pogłoski o dopełnieniu małżeństwa miała ceremonia ślubna ad instar sponsaliów de praesenti, połączona $z$ pokładzinami dzieci w Hainburgu. O zaślubinach hainburskich opowiadano $\mathrm{w}$ ten sposób, że słuchający kojarzyli to ze spotkaniem Wilhelma $z$ Jadwigą na Wawelu. Nie ulegli sugestii pomieszania tych dwu sytuacji opat żagański 76 i wyżej wspomniany rocznikarz z Klosterneuburgu, a Długosz, piszący o rzekomych wątpliwościach i skrupułach Jadwigi, wyraźnie nawiązuje do jej zaręczyn hainburskich, np. podając, że Jadwiga 15 dni przebywała w łożnicy $\mathrm{z}$ Wilhelmem ${ }^{77}$. Dodajmy, że Dopełnienie szamotulskie podając wiadomość o defektacji pościeli przez Wilhelma, miało chyba na myśli Wilhelma jako jeszcze chłopca w wieku dziecinnym ${ }^{78}$.

W Austrii utworzyło się pod wpływem propagandy dworskiej przekonanie, że Wilhelm miał już żonę w Krakowie, po której śmierci ożenił się po raz wtóry w Apulii. Tak podaje kartuz z Gaming w Chronicon Alberti, 380.

75 Rocznikarz z Klosterneuburgu przekazuje, że Wilhelm, który się ożenił z Joanną Neapolitańską, był niegdyś królem Polski. Gdy miał po raz pierwszy udać się z żoną do komnaty, baronowie i potężni panowie chcieli go zamordować. Wilhelm tedy uszedł potajemnie z Krakowa i nigdy więcej do niego nie wrócił. $\mathrm{Pa}-$ nowie wydali ponownie żonę Wilhelma wbrew jej woli za poganina, którego też ukoronowali na króla (ConClaustr, 736). Według rocznikarza klosterneuburskiego consummatio matrimonii $\mathrm{z}$ Wilhelmem nie nastąpiła.

${ }_{76}$ Ludolf, opat żagański, pisząc Katalog opatów swego klasztoru wyraźnie stwierdza, że Jadwiga była legalną żoną Jagiełły, a nie Wilhelma, gdyż kiedy ją zabrali z sypialni księcia Austrii, była młoda i niedojrzała. „Dicunt, quod licet inter eos fuissent sponsalia contracta, tamen propter defectum aetatis matrimonium nullum fuit". Książę austriacki jej cieleśnie nie poznał, jednakże utrzymywał, że Jadwiga jest jego żoną. Catalogus abbatum Saganensium, w: Scriptores rerum Silesiacarum oder Sammlung schlesischer Geschichtschreiber, (SRS), herausgegeben von G.A. Stenzel, Breslau 1835, I, 218.

77 „Neque enim a plurimorum notitia sciebat ignoratum, quod cum praefato Wilhelmo, duce Austriae, post contracta de praesenti sponsalia, quindecim diebus in thoro, carnali copula etiam subsecuta, manserat". Długosz, 461. Por. tenże, Liber beneficiorum, III, 470.

78 „1386, nobiles de Polonia Johannem [chodzi tu o Wilhelma], ducem Austriae, in Poloniam acciverunt, volentes eum regem constituere, ut qui quia puer erat, et ut dicebatur stratum Hedvigis, reginae Poloniae, pueriliter agens, turpiter concacavit - Johannes igitur, dux Austriae, de Polonia est eiectus". Dopelnienie Szamotulskie, MPH II, 862. Wiadomość o wezwaniu Wilhelma przez panów jest błędna. 
Do utworzenia opinii o Jadwidze jako bigamistce i cudzołożnicy nie mało mógł się przyczynić także wpływ postglosatorów bolońskich, interpretujących prawo rzymskie, z których komentarzem dwór wiedeński zapewne się spotkał. Według ich prawdopodobnego wykładu, opartego na Digestach justynianowskich, Jadwidze nie wolno było zrywać zaręczyn. Narzeczona według Digestów obowiązana była do wierności, a złamanie tejże było kwalifikowane jako cudzołóstwo ${ }^{79}$. Zawarcie drugich zaręczyn bez legalnego ustania pierwszych ulegało karze infamii. Zarzut ten o tyle uderzał $\mathrm{w}$ próżnię, że Jadwiga jako czteroletnie dziecko nie mogła złożyć świadomego konsensu, wymaganego do ważności zaręczyn, dlatego do zachowania wierności nie była zobowiązana.

Trzecią mistyfikacją habsburską, odnoszącą się do Wilhelma, było rozgłaszanie, że ich książę już objął rządy Królestwa Polskiego, jednakże na wezwanie matki Jadwigi, Elżbiety Bośniaczki, poganin Jagiełło zbliżył się $\mathrm{z}$ wielką siłą do Krakowa i przyjmując pozorny chrzest oraz przekupując polskich panów podarunkami, wypędził Wilhelma ze stolicy i zabrał mu żonę. Jadwiga bardzo kochała Wilhelma, swego pierwszego męża, dlatego postępek matki głęboko zranił jej serce, a ponieważ Elżbieta przekroczyła przykazania Boskie i kościelne, czyniąc z córki cudzołożnicę ${ }^{80}$, dlatego Bóg ją skarał, sprowadzając na nią gwałtowną śmierć ${ }^{81}$. Wilhelm więc chcial uchodzić $\mathrm{w}$ Wiedniu za wypędzonego, zdetronizowanego króla Polski, który czekał na okazję, aby do swej własności po-

"9 „Quaerebatur, an iure mariti possit accusare vir feminam, quae si desponsata fuisset, alii in matrimonium a patre fuisset tradita, respondit; novam rem instituere huiusmodi accusatorem existimo, qui adulterii crimen obicere desiderat propter hoc factum, quod priori sibi desponsata puella a patre, in matrimonium alii fuerit tradita” (c. V, s. 846). „De condictione ex lege. Paulus libro secundo ad Plautum. Si obligatio lege nova introducta sit nec cautum eadem lege quo genere actionis experiamur, ex lege agendum est". Tamże, XLVIII, 208.

80 „Wygnanie Wilhelma przez Jagiełłe”" było wczesną wersją Habsburgów, która na dworze wiedeńskim stale się utrzymywała. Kronika austriacka, współczesna wypadkom, pisała: „Der selb haiden cham gen Krakaw mit grosser macht und liez sich da tauffen, allain durch des künigreiche willen, alz etleich wellend. Der nam die frawn über irs herczen willen wider got und das rechte mit dem willen irr vaigen muter, an der got das grosz unrecht, als hernach geschriben stet, scheinperleich hat gerochen". ÓsterChron, 205. Podobnie i Ebendorfer (814) podaje, że matka Jadwigi pod wpływem szatana, za radą Mikołaja z Gary, swego palatyna, wysyła posłów do poganina, księcia Jagel z Litwy i nie wstydziła się wydać mu swej córki w celu nierządu (prostituere) i dać w zastaw (affidare) jako żonę. Jagiełło przybył $\mathrm{z}$ wielkimi siłami do Krakowa, przemocą zabrał Jadwigę i tak upokorzoną zaślubił. Opinię dworu habsburskiego o wygnaniu Wilhelma przez Jagiełłę autorytatywnie potwierdza członek tego rodu Elżbieta, królowa Węgier, wdowa po Albrechcie II, która w liście pisanym do Fryderyka III, w czasie walk z Władysławem Jagiellończykiem w r. 1441 wspomina, że Jagiełło przyjął chrzest po to, by dostać tron polski (a więc nieszczerze), odebrał księciu Wlhelmowi żonę, a jego wygnał z kraju. A.F. Kollar, Analecta Monumentorum Omnis Aevi Vindobonensis, t. II, Vindobonae 1762, col. 915-927; A. F. Grabski, Jadwiga - Wilhelm Jagielto w opiniach europejskich, ,Nasza Przeszłość” 23 (1966) 136.

81 Jest to aluzja do pojmania Elżbiety Bośniaczki w Diakowie 25 lipca 1386 przez magnatów chorwackich, a następnie do uduszenia jej przez nich z początkiem stycznia $1387 \mathrm{w}$ Novimgradzie dalmackim. 
wrócić. Wiadomości te są niezgodne $\mathrm{z}$ polskimi źródłami. Jagiełło nigdy w życiu Wilhelma nie widział, nie przyprowadził do Polski żadnej siły zbrojnej, owszem jadąc na koronację w otoczeniu książęcego orszaku złożonego z braci, krewnych i wybranych bojarów, prosił w Wołkowysku posłów polskich o glejt bezpieczeństwa dla siebie i swoich ${ }^{82}$.

Ostatnią mistyfikacją austriacką było jakieś nieokreślone udzielenie przez papieża Urbana VI „dyspensy” na drugie małżeństwo Jadwigi z Jagiełłą po wypędzeniu z Krakowa jej pierwszego męża Wilhelma. Habsburgowie więc obciążyli odpowiedzialnością za rzekomy konkubinat czy dwużeństwo Jadwigi papiestwo, które podobno miało jej dać pozwolenie na małżeństwo z Jagiełłą (Leopoldyni austriaccy trzymali w r. 1385 z Awinionem i nie uznawali legalności papieża rzymskiego). Nic nie wiadomo o podobnej prośbie ze strony Jadwigi, wysłanej przed ślubem z Jagiełłą. Według tych samych kronik Jadwiga miała Wilhelma kochać i wydana była za Jagiełłę przymusem, jakże więc mogła prosić o zezwolenie na zerwanie związku $\mathrm{z}$ umiłowanym? ${ }^{83} \mathrm{~W}$ rzeczywistości żadnej dyspensy nie było i nie było jej potrzeba, bo zerwanie zrękowin z Wilhelmem (o ile miały jakąkolwiek ważność) nastąpiło na mocy prawa, które każdemu zaręczonemu w młodocianych latach, kiedy nie posiadał należytego wieku do zawarcia małżeństwa, zezwalało na odwołanie narzeczeństwa zaraz po dojściu do pełnoletności. Nie ma zaś mowy, aby papiestwo dało „dyspensę” od ważnego małżeństwa. Wystarczy podać bliski tych czasów przykład. Około roku 1365 Kazimierz Wielki sam sfabrykował „dyspensę papieską" do małżeństwa z Jadwigą głogowsko-żagańską, gdy jeszcze żyła jego druga żona Adelajda Heska. Urban V wytoczył królowi proces o sfałszowanie dokumentu; proces ten $\mathrm{z}$ trudnością został umorzony w r. 1368. Małżeństwo nigdy nie otrzymało zatwierdzenia, a córki króla zrodzone $\mathrm{z}$ Jadwigi musiały być legitymowane (1371) ${ }^{84}$. Jak $\mathrm{z}$ tego widać, plotka habsburska o rzekomej papieskiej dyspensie super matrimonio rato et consummato dla małżeństwa Wilhelma z Jadwigą i to na korzyść nowego związku Jadwigi z Jagiełłą krzywdziła Stolicę Apostolską.

Omówiwszy powyższe cztery mistyfikacje habsburskie, przenieśmy się do kronik krzyżackich. Cechą ich jest wyzierająca spod pióra pisa-

4. Akta Unii, nr 2, s. 4.

83 Jagiełło, jako poganin, nie mógł prosić o dyspensę.

84 Z. Kaczmarczyk, Kazimierz Wielki (1310-1370), król polski, w: Polski Słow. nik Biograficzny, t. XII, 266. 
rza ślepa nienawiść do Jagiełły. Wśród zniewag skierowanych pod adresem wielkiego księcia litewskiego przewijają się takie określenia, jak że „Jagal” jest prześladowcą chrześcijan ${ }^{85}$, dzikim poganinem ${ }^{86}$, wściekłym psem ${ }^{87}$, fałszywym chrześcijaninem, który dla uzyskania polskiego tronu przyjął obłudnie chrzest ${ }^{88}$. Ponadto Krzyżacy przejęli opinie austriackie, że Jagiełło żyje $z$ Jadwigą $w$ konkubinacie, bo jego małżeństwo zawarte z polską królową jest nieważne, gdyż Jadwiga w czàsie zamążpójścia za Litwina miała już męża ${ }^{89}$.

Pogrobowcem tej zjednoczonej wrogiej kampanii habsbursko-krzyżackiej, która miała swe echo na międzynarodowym forum Soboru konstancjeńskiego ${ }^{90}$, był słynny humanista Eneasz Sylwiusz Piccolomini. Mimo że był electus confirmatus biskupstwa warmińskiego i szczycił się przyjaźnią kardynała Zbigniewa Oleśnickiego, związany z Habsburgami, powtarzał w swych dziełach, które miały wielką poczytność, że Jadwiga była legalną żoną Wilhelma, wskutek czego jej małżeństwo nie było prawomocne. Nie wiadomo, czy jako papież Pius II, zetknąwszy się $z$ Kurią rzymską, zapytany $w$ tej sprawie nie powiedziałby: „Aeneam reicite, Pium recipite".

85 Die Aeltere Hochmeisterchronik (1433-1440), w: Scriptores rerum Prussicarum, ed. T. Hirsch, M. Töppen, E. Strehlke, Leipzig 1866 (SRP), III, 608-610; Annalista Thorunensis, SRP III, 140-143, powiada, że najgorsi Polacy, Niemcom gwałtownie wrodzy, wygnali Wilhelma i wnieśli na tron Jagiełłę, najgorszego prześladowce chrześcijan (pod data 1386).

86 Die Aeltere Hochmeisterchronik, 608: Polacy zawezwali na tron dzikiego poganina zwanego Jagel; według Krzyżaków Jagiełło zrabował Wilhelmowi tak małżonkę, jak i Królestwo Polskie, dane przez ojca Jadwigi, Ludwika, wbrew świętemu Kościołowi - dla wzmocnienia sił litewskiego pogaństwa przeciw chrześcijanom. Lites ad res gestae inter Polonos Ordinemque Cruciferorum, II, Poznań 1892, 285, 154.

87 Die Altere Hochmeisterchronik, 610: Jagiełło „de boze Hunt”; Die Jüngere Hochmeisterchronik (1542), SRP 5, 120-121: Jagiełł ",der bose Hundt".

88 Starsza Kronika Wielkich Mistrzów [Krzyżackich] uważa chrzest Jagiełły za podejrzany (610). Podobnie i austriacki poeta dworski Peter Suchenwirt (zm. ok. 1396) oskarża Jagiełłę o fałszywe przyjęcie chrztu: „Ein haiden man sein frawen gab, Der falschlich war getauffet, Mer umb die leut und das lant, Denn umb den christenglauben". SRP III, 141.

89 Annaiista torúński oskarża Polaków, że zhańbili królową Jadwigę, wydając ją Jagielle w celu konkubinatu. Jadwiga bowiem była zaślubiona Wilhelmowi księciu austriackiemu, ,qui copula carnali matrimonium consummavit" (SRP III, 143). Oficjał Zakonu Krzyżackiego w Prabutach (Riesenburg), Johann v. Posilge (zm. 1405) pisząc swą Kronike (Chronik des Landes Preussen, SRP III, 141-145) opowiada, jak bardzo się Wilhelm z Jadwigą kochali, książę ,hatte beslofen Hedwig", tymczasem Polacy wypędzili Wilhelma, a wnieśli na tron polski Jagiełłę, który pojął Jadwigę za żonę. O dopełnieniu małżeństwa Jadwigi z Wilhelmem był również przekonany pisarz Starszej Kroniki Wielkich Mistrzów (608).

90 Na soborze w Konstancji $(1414-1418)$ była wygłoszona Satyra Jana Falkenberg, dominikanina, skierowana przeciw Polsce i Polakom (1416). Sobór potępił tę Satyre w r. 1418. J. Fijałek, Dwaj dominikanie krakowscy, Jan Biskupiec $i$ Jan Falkenberg, w 500-tna rocznice odwotania Satyry antypolskiej Falkenberga $w$ Rzymie 1424, Lwów 1925. 


\section{STOLICA APOSTOLSKA W OBRONIE MAEŻEŃSTWA JADWIGI Z JAGIEEEA}

Jako co dopiero ochrzczony neofita, osaczony w świecie europejskim przez wrogą akcję nie tylko Habsburgów, ale i zachłannego Zakonu Krzyżackiego stojącego wówczas u szczytu swej potęgi i poważania, Jagiełło odczuwał potrzebę oparcia się o Stolicę Apostolską. Dlatego niedługo po ślubie i koronacji (1386) za radą roztropnej małżonki i otaczających go panów polskich wysłał swego posła do Rzymu w sprawie złożenia papieżowi obediencji tak w swoim imieniu jako króla Polski jak i w imieniu nawróconego narodu litewskiego. Sprawa uznania małżeństwa Jagiełły z Jadwigą za legalne była z tym ściśle związana. Z tym ważnym poselstwem wybrał się do Rzymu prawdopodobnie Mikołaj Trąba. Wysłannik ten, wracając od papieża, wiózł dokument, który przedstawił na dworze wiedeńskim. O jego treści dowiadujemy się z Katalogu opatów żagańskich, napisanego niewiele lat później. Pisarz opactwa nazywa ten reskrypt „dispensatio apostolica" ${ }^{91}$. Nie była to dyspensa od narzeczeństwa, bo tu działały osobne przepisy prawa, a interwencja papieska przeciwstawiałaby się wolności małżeństwa. Nie mogła to być także dyspensa super matrimonio rato et consummato, bo Kościół roz-

91 Relacja podana w Katalogu opatów żagańskich, pochodząca od Ludolfa, zapisana została za życia królowej Jadwigi. Jako świadectwo współczesne, jeszcze z XIV w., tekst ten ma niezmiernie wielkie znaczenie dla życiorysu Jadwigi, dlatego warto przytoczyć go w całości: „De rege Polonorum. Hiis diebus, mortuo iam dudum Kazimiro rege Polonorum sine herede, cum filia minor regis Ungarorum jus successionis in regno Polonorum haberet, pater ejus eam duci Austriae desponsavit. Sed post mortem patris, Poloni eam auferentes duci, cuidam gentili, sed tunc a primo baptizato forte Vladislao vel Wolislao nomine in conjugio copularunt ipsumque neophitum super se regem facerunt, qui tenens regnum Polonie usque in diem istum habet et eandem regis filiam in uxorem, licet sterilem et sine parole. Dicunt autem, eam huius secundi et non primi jam uxorem esse legittimam, quia cum eam tulerunt de cubili ducis Austrie, tam juvenis et impubes exstitit, quod licet inter eos fuissent sponsalia contracta, tamen propter defectum etatis matrimonium nullum fuit, presertim quia, ut ipsi dicunt, eam dux Australium nunquam carnaliter cognovit. Ille autem asserens eam uxorem suam et forsan a se cognitam nondum, quamvis aliam voluit ducere nec ducet forsitan ea vivente. Ad hunc ducem quidam veniens et dispensationem apostolicam, quam sine suo mandato impewavit, ostendens, ut si eam carnaliter non cognovisset, eciam si inter eos velud puberes matrimonium extitisset, aliam ducere posset, incarceratus accepit laboris sui premium, donec per supplicationem multorum fuit redditus libertati. Ipsa autem regina, operibus bonis plena, Deo non mundo militant, humilitati vacans, superbire penitus ignorat et magistros virosque doctos Deum timentes a longiquis ad se partibus non minimum pro suo et aliorum salute laborat”. Dopisek z XV wieku: „Post mortem dicunt eam miraculis claruisse et hucusque ad tumbam ipsius, quamvis non canonizata, asscrunt miracula fieri". SRS, 218. A. F. Grabski w art. Jadwiga Wilhelm - Jugretło w opiniach europejskich, „Nasza Przeszlość” 23 (1966) na s. 129 i 149 tłumaczy dwa wyjątki z powyższego tekstu, ale popełnia błędy. I tak przy tłumaczeniu ,Ille autem asserens eam axorem suam et forsan a se cognitam nondum” opuścil ",nondum”, co dało sens przeciwny, a przy tekście: „ut si carnaliter non cognovisset, eciam si inter eos velud puberes matrimonium extitisset" tłumaczy „etiam si” przez ,a także gdyby”, a nie „nawet jeżeli”, ,choćby nawet”, co również zmienia sens zdania. 
wodów nie uznawał. Raczej była to deklaracja „nullitatis sponsalium" między Wilhelmem a Jadwigą i oświadczenie, że Wilhelm, który Jadwigi nie poznał, może, mimo ceremonii małżeńskiej odbytej w dzieciństwie ad instar nuptiarum adultorum, pojąć inną za żonę. Stolica Apostolska nie była zwykła wydawać decyzji bez dokładnego rozeznania, zwłaszcza w tak delikatnej sprawie i dlatego nie mogła dopuszczać możliwości zawarcia przez Jadwigę $\mathrm{w}$ latach dojrzałości jakiegoś małżeństwa z Wilhelmem. Mikołaj Trąba złożył niezawodnie wyjaśnienie, że Jadwiga zaraz po dojściu do lat sprawnych weszła w związek małżeński z Jagiełłą. „Velud puberes" oznacza tylko wzorzec, według którego Jadwiga zawarła małżeństwo z Wilhelmem w Hainburgu. Nazywanie tej deklaracji „dyspensą” nie jest uzasadnione. Przywiezienie jej do Wiednia przez posła polskiego stało się przyczyną jego aresztowania.

Papieża Urbana VI niepokoiła wielka siła propagandy antyjagiellońskiej, zarzucającej wielkiemu księciu litewskiemu przyjęcie chrztu bez szczerej intencji i porwanie cudzej żony. Dlatego w lecie (w czasie od lipca do początku września 1386) wysłał do Polski mediolańczyka Maffiola di Lampugnano, arcybiskupa Raguzy, jako swego legata, aby na miejscu zbadał sprawę nieustannych zarzutów krzyżackich. Przyjęty życzliwie przez Jagiełłę i Jadwigę, wykazywał dużo zrozumienia i uznania dla dzieła pary królewskiej. Nawiązując do deklaracji zgłoszonej w Rzymie przez Mikołaja Trąbę, Maffiol odebrał przysięgę posłuszeństwa i wierności od narodów polskiego i litewskiego. Dnia 24 lipca 1386 legat wysłał orędzie do wszystkich elektorów Cesarstwa Rzymskiego na ręce arcybiskupa kolońskiego Fryderyka III von Saarwerden, w którym wychwalał króla Władysława, jego nawrócenie i pracę misyjną. Relacjonował o małżeństwie Jagiełły $\mathrm{z}$ Jadwigą $\mathrm{i}$ o złożeniu przysięgi obediencyjnej. Wzywał adresatów, aby dla miłości i wzrostu wiary chrześcijańskiej zechcieli uznać owego pana Władysława, króla Polski, za najprawdziwszego wyznawcę wiary chrześcijańskiej i to ze względu na szacunek, jaki mają dla Stolicy Apostolskiej ${ }^{92}$. Po raz drugi Kuria rzymska biorąc w obronę Jagiełłę przeciw propagandzie krzyżackiej, stanęła po stronie ważności małżeństwa Jadwigi z wielkim księciem litewskim.

W tym czasie, kiedy Maffiol zdążał w swej legacji do Polski, dnia 9 lipca 1386 poległ w bitwie pod Sempach Leopold III, jednak wojna ze Szwajcarami dalej trwała, aż z końcem tego roku doszło do rozejmu

92 Maffiol pisze w swym liście: ,illustrem principem Wladislaum regem Poloniae invenimus cum humilitatis devotione sacramentum baptismatis recepisse, inter quem et praeclaram principem dominam Hedvigem reginam Poloniae disponente Domino extat matrimonium laudảbiliter consummatum; dictusque dominus Wladislaus in manibus nostris tactis evangeliis prestitit iuramentum, quod ex nunc et in antea velit esse obediens Sanctae Romanae Ecclesiae, domino Urbano papae moderno et eius successoribus ad Sedem apostolicam canonice sublimandis". Codex epistolaris saec. XV, II, nr 8, s. 10. 
między Habsburgami a wojskami szwajcarskimi. Wówczas Austria porzuciła zupełnie papieża awiniońskiego i przeszła do obediencji rzymskiej. Habsburgowie od razu wykorzystali tę zmianę po to, aby w lutym 1387 wnieść skargę do Urbana VI, spodziewając się, że papież, ciesząc się z ich akcesu, przyjmie łaskawie ich zażalenie przeciw ważności małżeństwa polskiej pary królewskiej ${ }^{93}$. Głównym argumentem było zapewne nie dochowanie obowiązku wierności narzeczeńskiej przez Jadwigę. Austriacką stronę procesową poparł wielki mistrz krzyżacki, uważający za skandal tę okoliczność, że Jagiełło przyjął chrzest nie z rąk pobożnego zakonu, który mógł sprawdzić szczerość nawrócenia poganina, lecz z Polski, gdzie rządziła dziewczynka-królowa i przekupieni panowie, kierujący się względami politycznymi, co oczywiście nie dawało żadnej gwarancji, że Jagiełło naprawdę obrócił się ku Chrystusowi, owszem, stwarzało obawę, że Litwin, mimo chrztu, w głębi serca pozostał nadal poganinem. Sojusz Polski z Litwą - zdaniem Krzyżaków - nie przyniósł pożytku Kościołowi, lecz wzmocnił siły pogaństwa litewskiego.

Proces Habsburgów przeciw małżeństwu Jadwigi z Jagiełłą toczył się $\mathrm{w}$ Rzymie $\mathrm{z}$ największą intensywnością $\mathrm{w}$ roku 1387. Obie strony, tak austriacka, jak i polska, wyznaczyły swoich przedstawicieli prawnych, zwanych prokuratorami. Z polskiej strony stawał zapewne Piotr Wysz ${ }^{94}$, kłéry wówczas bawil na studiach we Włoszech, wybitny kanonista, późniejszy biskup krakowski. W gorącym okresie procesowym wmieszał się w tę sprawę sam papież, wysyłając do Polski po raz wtóry swego legata, kardynała Bonawenturę Baduario Peraga ${ }^{95}$, który zapewne przy tej okazji omawiał również sprawę ewangelizacji Litwy i założenia w niej bisKupstwa. Papież z pewnością przewód sądowy brał poważnie, dopuszczał dewody $z$ obu stron, ale tenor listu pisanego przez niego przy końcu roku 1387 (z $30 \mathrm{XII}$ ) do książąt mazowieckich Janusza i Ziemowita oraz kilłu panów małopolskich ${ }^{96}$ potwierdża, ,że papież przyznaje słuszność krakowskiej parze królewskiej, choć ze względów taktycznych liczył się $z$ zym, że proces nie jest jeszcze zakończony". Urban VI wyznaje w tym liście, że z radością powitałby Jagielłę jako syna Stolicy Apostolskiej, gdyby nie proces książąt austriackich i skargi wielkiego mistrza Krzyżaków. Zastrzeżenia te już w początkach przyszłego roku (1388) znikły.

n Maciejewska, 65-66.

"4 S. Kijak, Piotr Wysz, biskup krakowski, Kraków 1923, 3; Maciejewska, 79: M. Gębarowicz, Psalterz floriański, Wrocław-Kraków 1965, 23.

9.5 O legacji kardynała Bonawentury Baduario da Peraga podaje wiadomość Crsnica Carrarese, napisana przez Galazzo Gatari, w 1. 1334-1405, dopelniona przez braci Andrea i Bartolomeo. Opowiadanie o królowej Jadwidze ułożone przez A. Ga¿ar $\mathrm{r}$ jest raczej legendą niż relacją historyczną. Wg Gatariego Wilhelm i Jadwiga zetwali zaręczyny na podstawie wzajemnej zgody, wyrażonej listownie. P. F. PaZumbo, Bonaventura di Peraga, w: Enciclopedia Cattolica, Citta del Vaticano, brw, II, col. 1846-1847.

36 Codex epistolaris Vitoldi, Kraków 1882, nr 36, s. 15. 
12 marca 1388 papież przychylił się do prośby Jagiełły i Jadwigi, których nazywa w bulli swymi najdroższymi w Chrystusie synem i córką i upoważnił posła królewskiego Dobrogosta biskupa poznańskiego do erekcji w Wilnie kościoła katedralnego pod wezwaniem św. Stanisława oraz do przeniesienia Andrzeja biskupa sereteńskiego na biskupstwo wileńskie. Bulla zawiera pochwały dla Jagiełły, który z pomocą Bożą, oświecony łaską Ducha św., doszedł do poznania prawdziwej, katolickiej wiary ${ }^{97}$. W następnym miesiącu (17 kwietnia) Urban VI wyraził radość z powodu chrztu Jagiełły i rozszerzenia wiary Kościoła rzymskiego, pochwalił króla polskiego za nawrócenie się, budowę kościołów i opiekę nad osobami kościelnymi, o czym mu złożył relację biskup Dobrogost. Jagielle dał papież zaszczytny tytuł „princeps christianissimus” ${ }^{98}$. Kwietniowa bulla gratulacyjna z r. 1388 jest trzecim z kolei dowodem uznania przez Stolicę Apostolską legalności małżeństwa Jagiełły z Jadwigą, jak też i potwierdzeniem szczerości nawrócenia wielkiego księcia litewskiego. Niedługo potem zakończył się proces austriacki. Wilhelm, wezwany przez papieża do stawienia się w Kurii, odmówił wyjazdu do Rzymu i jego sprawa upadła ${ }^{99}$. Nie przestał jednak dalej wysuwać swych pretensji do Królestwa Polskiego, a po śmierci Jadwigi uważał się za dziedzica polskiego tronu ${ }^{100}$.

Mimo kilkakrotnego potwierdzenia małżeństwa Jagiełły i Jadwigi przez Stolicę św., kronikarze austriaccy i krzyżacy nie przestali szkalować królowej Jadwigi jako nieprawej żony Jagiełły; bo - według nich - jej rzeczywistym mężem miał być Wilhelm. Kroniki krzyżackie przypisują Jadwidze niechęć do Jagiełły, którego nię uważała za. swego legalnego męża, dlatego miała się od niego odwracać, gdy się do niej przybliżył; spowiednikowi, który jej nakazywał uległość wobec Jagiełły: kazała milczeć; na twarzy nosiła czarną zasłonę ${ }^{101}$. Wszystkie te plotki krzyżackie opierały się o opinię głoszoną przez nich, że Jadwiga była konkubiną Jagiełły. Prawdopodobnie Jadwiga nosiła czarną zasłonę na twarzy, ale nie po to, żeby przed Jagiełłą zakrywać swoje oblicze, lecz by wyrazić żałobę po śmierci kochanej matki.

Zwraca uwagę ciekawy fakt, że pisarze wrogo nastawieni do krakowskiej pary królewskiej, którzy dawali do poznania, że znajạ nawet drob-

97 Kodeks dyplomatyczny katedry wileńskiej, wyd. J. Fijałek, W. Semkowicz, Kraków 1948 (KDWil), nr 10, 20-22.

98 Tamże, nr 12, 22-24.

99 Ebendorfer (819-820) usprawiedliwia księcia Wilhelma, że nie było dla niego godną rzeczą contendere pro meretrice.

100 Po śmierci Jadwigi wielki mistrz doradzał Wilhelmowi poprzez swego komtura wiedeńskiego, co ma czynić, aby usunąć tego, który się zwie królem polskim. Ćodex Diplomaticus Prussicus, ed. J. Voigt, Königsberg 1861, VI, nr 87, s. 91.

101 Aeltere Hochmeisterchronik, 608-610; Annalista Thorunensis, SRP III, 140--143; J. v. Posilge, Cirronik des Landes Preussen, SRP III, 306; K. Bitschin, Fortsetzung zu Peter von Dusburg Chronik, SRP III, 481. 
ne szczegóły z ich pożycia, nic nie wiedzieli o procesie królowej Jadwigi o zdradę małżeńską, który Długosz opisał pod r. 1389. Według niego Jadwiga złożyła przysięgę w obronie swej niewinności przed Jaśkiem z Tęczyna kasztelanem wojnickim, a 12 rycerzy wyzwało oszczercę Gniewosza z Dalewic na sąd Boży. Skazany Gniewosz musiał wejść pod ławę i psim głosem odszczekać swe kłamstwo ${ }^{102}$. Nie tylko pisarz Starszej Kroniki Wielkich Mistrzów [Krzyżackich], który tak się interesował tym, co się dzieje w Krakowie, nic o zarzutach stawianych królowej nie wiedział, ale też i w księgach sądowych całego województwa krakowskiego nie znajdujemy żadnego śladu wiadomości o procesie, wytoczonym Gniewoszowi o cześć królowej. Rycerz z Dalewic w dalszym ciągu cieszy się łaskami królewskimi i ciągle awansuje. Poza tym prawo polskie nie przewidywało kary odszczekiwania kłamstwa pod ławą psim głosem. Proces o cześć królowej nie miał miejsca. Nie wskazują nań dokumenty ani okoliczności. Zapisał tę wiadomość Długosz po 80 latach. Zdaje się, że była ona późnym i zniekształconym echem tradycji o procesie habsburskim.

Ostatnim, już czwartym z rzędu potwierdzeniem przez Stolicę Apostolską świętości związku Jadwigi z Jagiełłą jeszcze za życia królowej, było przyjęcie przez papieża Bonifacego IX godności ojca chrzestnego spodziewanego dziecka Jadwigi i Jagiełły. Do Rzymu został wysłany kanclerz królowej, elekt poznański Wojciech Jastrzębiec. Papież przekazał królestwu pełen wielkiej życzliwości list z tej okazji i upoważnił Jastrzębca, aby go zastąpił w tej funkcji. Wyrazem szczególnych względów dla Jadwigi i jej męża było życzenie papieża, aby dziecku nadano jego imię ${ }^{103}$. Gdy przypomnimy sobie sprawę Kazimierza Wielkiego, który za życia żony Adelajdy zawarł drugie małżeństwo i spotkał się z papieskim potępieniem i nieuznaniem jego dzieci za ślubne, przekonywujemy się, że mimo oszczerstw austriackich i krzyżackich, Stolica Sw. z największą czcią odnosiła się do związku małżeńskiego, jaki Jadwiga zawarła z Jagiełłą, uważając go za legalny i sakramentalny.

102 Długosz, 481-482; 85 par. Statutów wiślickich brzmi: „Id quod sum locutus, sum mentitus sicut canis". Nie ma mowy o wchodzeniu pod lawę sądową: Rozbiór krytyczny Annalium Poloniae Jana Długosza, praca zbiorowa pod kier. J. Dąbrowskiego, Wrocław-Warszawa-Kraków 1961, 24.

${ }_{103}$ List Bonifacego IX do Jagiełły. Długosz, 530-531; Tenże papież pisał do królowej Jadwigi. Długosz, 532-534. 


\section{SYLWETKA DUCHOWA KROLLOWEJ JADWIGI}

Jadwiga jest nazywana najpiękniejszą postacią niewieścią naszych dziejów. Nie chodzi tu tylko o piękność fizyczną, z której słỷnęła daleko w świecie, a która była dziedzictwem Piastówien mazowiecko-kujawskich ${ }^{104}$, lecz o zalety ducha tej mądrej i dobrej królowej.

Rzeczywiście tym, co najpierw uderzało w jej postaci, był wielki nad wiek rozsądek i mądrość polityczna, odziedziczona po babce Elżbiecie Łokietkównie, która była jedną z najwybitniejszych kobiet wśród monarchiń Europy. Zdolności dyplomatyczne Jadwigi, kiełkujące już na dworze węgierskim, rozwinęly się bogato przy boku dawnych doradców Kazimierza Wielkiego i jego siostry, regentki Elżbiety.

Jadwiga była bez wątpienia wielką królową, lecz katolicy polscy pragną w niej widzieć nie tylko znakomitość krajową, ale również postać podniesioną do wyżyn doskonałości chrześcijańskiej i stąd od wieków nazywają ją „błogosławioną”, a nawet ,świętą”. Zawsze wierzono, że była ubogacona cnotami, które wyliczali kronikarze, a jej obraz utrwalił się w pamięci Polaków na tle krucyfiksu z katedry wawelskiej.

Każdy łatwo przyzna, że królowa nie była świętą $w$ rodzaju średniowiecznych bohaterów umartwienia chrześcijańskiego. Wprawdzie nosiła włosiennicę i zachowywała posty, ale te dzieła cnoty wstrzemięźliwości pozostawały, w myśl zaleceń Chrystusa, ukryte w komórce jej życia wewnętrznego. Jest to zgodne $\mathrm{z}$ dążeniem mistyków $\mathrm{z}$ końca średniowiecza, którzy przeciwstawili się przeakcentowywaniu w ascezie zewnętrznych praktyk pokutnych. Jadwiga rozczytana w Piśmie św., wpatrzona w przykład Chrystusa, pamiętała, że tylko ziarnko, które obumrze, przynosi stokrotny owoc, ale na swoim dworze zachowywała i naturalność w obejściu, w manierach towarzyskich, w rodzaju pokarmów, ubiorów, etykiety w przyjmowaniu gości. Mimo atmosfery gorącej religijności, nie znajdujemy na dworze Jadwigi żadnych śladów bigoterii. Przypomina się nam Chrystus, który brał udzial w godach małżeñskich, zasiadal do uczty $\mathrm{z}$ faryzeuszami i grzesznikami. Przez to zastosowanie

10 Piękność fizyczną Jadwigi opisuje kilkakrotnie oparty o miejseową tradycję J. Dlugosz, np: ,virginem praedictam regiam adeo venustam decoramque existere, ut pro illa tempestate in orbe universo parem in forma non habere credita sit" (450). Wieść o jej piękności doszła do Włoch, gdzie Kronika Padewska Andrzeja Gatariego opowiada: "Avete a sapere, come per tutte le parti del mondo era nota la chiara e splendida bellezza della sopranarrata regina" (Scriptores rerum Italicartkm, ed. L. Muratori, Mediol. 1730, XVII, 502). Nawet niechętna Jadwidze Starsza Kronika Wielkich Mistrzów (609) nie szczędzi jej pochwał: „Gar eyn schone weib von gestalt und an czucht was dy Hedwig also das umb iren willen des koniges hoff vil besuches hatte". Uroda Jadwigi była pochodzenia polskiego; słynęły z niej księżniczki piastowskie: córki Ziemowita IV Mazowieckiego, zwlaszcza Cymbarka, żona Ernesta Żelaznego, brata Wilhelma austriackiego, matka cesarza Fryderyka III, także babki Jadwigi, Elżbieta Łokietkówna i Elżbieta księżniczka gniewkowska i matka naszej królowej, Elżbieta Bośniaczka. 
zasady libertatis christianae Jadwiga jest bliska współczesnemu człowiekowi, który kochając Kościół i uznając wymogi prawa Bożego, ogłoszonego przezeń mocą apostolską, jest ogromnie uwrażliwiony na zbędne krępowanie ludzkiej wolności niezrozumiałymi przepisami i ograniczeniami.

Współcześnie szczególnie się podkreśla, że pokój jest najwyższym ideałem ludzkości. Nie chodzi tylko o pokój wewnętrzny duszy i serca, ale i o pokój świata, stanowiący przedmiot trosk dyplomatów, odpowiedzialnych za przyszłość narodów. Pokój powszechny to prastary przedmiot modlitw Kościoła; wołanie o treuga Dei stało się pod pewnym względem nowoczesnym ideałem, którego chęć realizacji głęboko tkwiła w duchowości Jadwigi. Młodziutka władczyni cieszyła się, że nawrócenie Litwy ${ }^{105}$ odbywa się przy jej współudziale w sposób pokojowy a nie na wzór działania Krzyżaków, którzy nie widzieli niczego złego w tępieniu i mordowaniu pogańskich „Saracenów” i przy pomocy miecza chcieli Litwę doprowadzić do chrześcijaństwa. Jadwiga w sposób pokojowy zajęła Ruś Halicką przez jej ojca odebraną Polsce. W podobny sposób pragnęła załatwić sprawę krzyżackich zaborów ziem polskich. Widząc złą wolę Zakonu nie godziła się na zrezygnowanie przez Polskę z praw do zagarniętych ziem, sądziła bowiem, że utrzymanie pokoju daje się pogodzić z wymogami sprawiedliwości. Choć dzieli nas od niej sześć wieków, jest nam bliska przez miłość pokoju nakazaną przez Ewangelię. Dała nam rzadki w średniowieczu przykład, jak czyniąc pokój, którego przygotowanie jest obowiązkiem każdego człowieka można dojść do synostwa Bożego. Dzieło Jadwigi było podwaliną tego niezwykłego fenomenu w dziejach Europy: gdy w innych państwach szalały prześladowania religijne i w imię wiary toczyły się wojny i paliły stosy, w Polsce panowała tolerancja.

Prawdziwy pokój może być zbudowany na poszanowaniu godności osoby ludzkiej. Szacunek dla tej godności, którą Jadwiga widziała w każdym człowieku, wyrażał się u niej w niezwykłej pokorze, podziwianej przez współczesnych, wspominanej we wszystkich nekrologach, zapiskach i wczesnych pamiętnikach. Poczucie własnej nietykalnej godności przejawiło się $\mathrm{w}$ jej stosunku do Wilhelma. Żądał on od niej wierności dla zobowiązań rodzicielskich (a wierność zaliczała się w systemie feudalnym do najwyższych cnót społecznych), Jadwiga natomiast zaakcentowała swą godność sprzeciwiając się pogwałceniu swej wolności przez

105 Cześć Jadwidze z powodu nawrócenia Litwy oddaje autor tzw. Pierwszej Kontynuacji Kroniki Detmara z Lubeki (1395-1399), który pod datą jej śmierci (1399) nazywa Jadwigę ,de ebare koniginne van Krakowe” i tak opisuje jej zasługi: ,God van hemmele gaff er grot ghevel, dat bi ever tit wart nicht allene bekeret de coning, ere here mer dat gantze land tho Lettiuwen". Die Chroniken der deutschen Städte, t. 26, Leipzig 1899, 110-111. 
śluby zawarte bez jej świadomego udziału. Wyraziła to w słowach, ,si qua fuerunt", wypowiedzianych w czasie rewokacji zaręczyn, zawartych $\mathrm{w}$ imieniu dzieci przez rodziców. Był to zarazem wyraz przełọnania; że z godnością ludzką wiążą się nienaruszalne prawa. Na tej godności opierają się także obowiązki człowieka, a to wiąże się z zagadnieniem jego szczęścia.

Osiągnięcie osobistego szczę́sia było pragnieniem serca Jadwigi. Realizację swego szczęścia widziała w spełnianiu wymagań i obowiązków, nałożonych przez godność ludzką, i ukochaniu wszelkiego dobra na świecie. Te ogólne zasady rozwiązywała $\mathrm{w}$ duchu chrześcijańskiego poglądu na świat. Chrześcijaństwo dawało jej gwarancję osobistego szczęścia. Pierwszym obowiązkiem była dla niej cześć Boża. W dziecięcej ufności w Ojca Niebieskiego chwaliła Stwórcę modlitwą psałterzową i rozmyślaniem nad lekturą religijną. $\mathrm{Na}$ drugim miejscu ceniła oparty na wymaganiach ludzkiej godności ideał miłości człowieka. Widząc w bliźnim drugiego Chrystusa, pełniła pokornie służbę miłosierdzia, nie omijając nadarzających się sposobności, by ulżyć doli ubogich, fundując między innymi szpitale dla chorych. Szukając dobra na świecie, wyraziła dobrowolną decyzję poślubienia Jagiełły, który przyrzekł doprowadzić do chrześcijaństwa ostatni naród pogański w Europie. W tym samym celu szerzenia dobra starała się o odnowienie Krakowskiej Wszechnicy.

Omawiając zagadnienie szczęścia nie można pominąć problemu cierpienia, które nie ominęło Jadwigi. Dwór wiedeński miał do niej żal, że uchylając się od oddania ręki Wilhelmowi pozbawiła Habsburgów Królestwa Polskiego, Krzyżacy nie mogli darować i Jadwidze i Jagielle, że ich małżeństwo odebrało im pretekst do posuwania się w głąb ziem litewskich; jedni i drudzy rozsiewali oszczercze insynuacje na jej temat.

Kroniki austriackie (a wtóruje im Długosz) przypisują Jadwidze wielką miłość do Wilhelma. Można w to wątpić, bo wychodząc za Jagiełłę (18 II 1386), mało Wilhelma pamiętała. Wyjście jej za mąż w tak młodym wieku (12 lat) nie było $w$ małżeństwach dynastycznych czymś wyjątkowym. Matka jej w czasie zamążpójścia liczyła 13, babka Łokietkówna - 15 lat. Bywało i odwrotnie: Jan Luksemburg mając lat 14 ożenił się z 18-letnią dziedziczką Czech. Nie można jednak wykluczyć, że to małżeństwo nie spełniło serdecznych życzeń Jadwigi. W pierwszym roku po ślubie straciła matkę, zmarłą tragicznie, a w 8 lat później siostrę Marię Węgierską. Sama - zdaje się - nie cieszyła się najlepszym zdrowiem i spodziewała się wczesnej śmierci. Tradycja podaje, że gdy ból przenikał jej duszę, biegła wylewać łzy przed czarnym krucyfiksem w katedrze wawelskiej, który - według legendy, zanotowanej po raz pierwszy w 1602 r. - miał do niej przemawiać. Krucyfiks ten powstał - jak wykazały badania naukowe - około roku 1380 , 
a więc wisiał już w katedrże w tym czasie, gdy Jadwiga przyjechała do Krakowa. Nie można wątpić, że był świadkiem jej modlitw, dlatego słusznie się nazywa „krucyfiksem Jadwigi”, tym bardziej, że od wieku XVII publiczny kult błogosławionej królowej zogniskował się raczej przy Ukrzyżowanym, niż przy jej grobie. Jadwigę bolał brak potomka, na którego czekał tak Jagiełło, jak naród polski. Powiwszy córkę ElżbietęBonifację, zmarłą na skutek nieszczęśliwego porodu, Jadwiga była pewna, że i ją czeka rychła śmierć i przygotowywała się na nią z zupełnym poddaniem się woli Bożej. Ostatnie chwile jej życia, opisane przez Długosza ${ }^{106}$, świadczą o wysokim stopniu jej zjednoczenia z Bogiem.

Jadwiga rozumiała głos krzyża, podobnie jak i św. Franciszek z Asyżu, od którego Chrystus miał również z krzyża przemawiać. Z zakonem św. Franciszka była królowa szczególnie związana. Ideał franciszkański ${ }^{107}$ odpowiadał jej, gdyż już na Węgrzech, przy boku pobożnej babki Łokietkówny, zetknęła się ze szczerymi formami nabożeństwa serafickiego miłośnika Chrystusa, a przybywając zza Dunaju nad Wisłę, pogłębiła związek z prostotą i pokorą asyskiego zakonu.

Tu na zamku krakowskim dawały przykład bogobojnego życia późniejsze córki św. Franciszka, klaryski: bł. Salomea Piastówna, bł. Kinga, Węgierka, księżna krakowska i prababka Jadwigi, bł. Jolanta, księżna kalisko-wielkopolska. Andegawenka była tak samo świętą żoną jak one, a nawet w szczególniejszy sposób bardziej niż one, stała się bowiem wzorem już nie tylko dla kapłanów i zakonnic, ale dla ludzi świeckich, którzy w obecnych czasach potrzebują nowoczesnego wzoru świętości. Mimo oddalenia w czasie jest tak nam bliska, jak gdyby wczoraj odeszła, budząc wspomnienie wzruszającej ludzkiej dobroci i związanej z nią nadprzyrodzonej piękności jej duszy ${ }^{108}$.

106 Długosz, 531.

107 Duch ascezy franciszkańskiej nosił następujące cechy: a) wyrzeczenie się wszelkiego przywiązania do rzeczy doczesnych i połączona z tym niezmącona niczym radość (Bóg mój i wszystko moje), oddanie się zupełne Bogu; b) najwyższa uprzejmość dla bliźnich (caritas); c) najgłębsza pokora (humilitas) połączona ze współczuciem dla wszystkiego, co cierpi; d) miłość pokoju, szczerość i otwartość serca (bonitas). Jest to pobożność specyficznie chrystologiczna, która się u św. Franciszka przejawiła od budowy żłóbka w Greccio do otrzymania stygmatów w La Verna. Slady pobożności typu franciszkańskiego możemy znaleźć w życiu Jadwigi, jeżeli przestudiujemy dokumenty jej czasów i wzmianki w Historii Długosza.

108 Autor niniejszej pracy opiera swe określenie duchowości królowej Jadwigi na rodzaju jej wychowania, które z pewnością miało cechy pobożności franciszkańskiej, przy boku rodziców i babki Elżbiety Łokietkówny. Dwór zaś krakowski miał silne powiązania z zakonem franciszkańskim z tytułu fundacji klasztorów reguły św. Franciszka i działalności księżniczek krakowskich, mniszek w konwentach św. Klary. Dotychczas ukazały się dwie prace o duchowości królowej Jadwigi. Jedną z nich opublikował prof. Karol Górski (Osobowość królowej Jadwigi na tle religijności średniowiecza, „Polonia Sacra” 2 (1949) 224-232). Autor definiuje postawę religijną Jadwigi jako praktycystyczną, charakterystyczną dla XIV wieku. Postawa ta wykazywała pogardę dla scholastyki, co jednak u Jadwigi musimy wykluczyć, bo królowa widziała największy skarb Kościoła polskiego nie tylko w jego 


\section{HEDVIGE ET WILHELM}

\section{$\mathrm{R}$ é $\mathrm{s}$ u m é}

Les rapports d'Hedvige d'Anjou, princesse hongroise (née le 15 II 1374 à Buda) reire de Pologne dans les années 1384-1399, avec son fiancé de l'époque d'enfance, Wiitelm Habsbourg, prince autrichien (né en 1370), futur mari de Jeanne II Napoliteine, n'ont pas été jusqu'à présent suffisamment éclaircis. Ce n'est que d'une réponse définitive, très detailée de la précision, exacte de son caractère dépend le problème actuel de sa béatification - qui est en train d'être réalisée à Rome. Ce moment suprême exige que sa personne soit liberée des toutes fausses accusations.

Hedvige est devenue fiancée de Wilhelm par une entente entre les parents, arrangée d'abord par correspondance. Le renouvellement des fiançailles, appellé ,le mariage de Hainburg" a eu lieu le 15 VI 1378, sous la forme de ,sponsalia de presenti", avec la mise au lit imitant le mariage des adultes. Une déclaration fut annoncée ensuite par les parents d'Hedvige à Zwoleń en 1380. Au point de vue de l'Eglise les fiançailles contractées par les enfants qui n'étaient pas encore suffisament âgés pour se servir de la raison (c'est à dire l'âge de sept ans) n'étaient pour eux valables. L'accomplissement des obligations des fiançailles confirmées après l'âge de sept ans, mais avant l'âge mûr (14 ans chez les garçons, 12 ans chez les filles) qui n'ont pas été révoquées selon un accord réciproque, devenaient irrévocables si au seuil de la maturité l'une des parties sans demander l'accord de l'autre, ..statim", c'est à dire dans trois jours après avoir atteint l'âge de la maturité, n'a pas révoqué devant l'autorité de l'Eglise ses fiançailles.

L'accomplissement des obligations des fiançailles entre les adultes était un devoir sous peine de péché, parce qu'elles traitaient „quoddam sacramentale" (Saint Thomas d'Aquin) et touchait le fait de ,gravis momenti". On ne pouvait pas quand même appliquer pour la rupture des fiançailles un châtiment conventionnel, ou demander par l'intervention du tribunal leur accomplissement (in foro contentioso)

misji ewangelizacyjnej pod kierownictwem hierarchii, lecz także i w rozwoju teologii, której mistrzów sprowadzała do Krakowa. Ona także przeprowadziła erekcję wydziału teologicznego w Krakowie i bursy uniwersyteckiej w Pradze. Górski zwracając uwagę na Jana Szczeknę, przybyłego na dwór Jadwigi najpóźniej w r. 1397, domyśla się u królowej wpływów mistyki cysterskiej, której istotą było upodobnienie własnej woli do woli Boga. Do tej mistyki mogły się dołączyć wpływy dominikańskie poprzez traktat darowany przez Henryka Bitterfelda De vita contemplativa et activa. Drugą pracą o duchowości Jadwigi był odczyt ks. prof. Jerzego Wolneg J, który postawił hipoteze, że traktat Bitterfelda był napisany w duchu mistyków nadreńskich i że Jadwiga rozwijała się w duchu zawartych w nim wskazań (D. Mieth, Die Einheit von Vita activa et contemplativa in den deutschen Predigten und Traktaten Meister Eckarts und bei Johannes Tauler, Regensburg 1969). Można tu zauważyć, że duchowość Jadwigi w czasie otrzymania księgi Bitterfelda była już uformowana, a w tekście Bitterfelda trudno jest dopatrzeć się wyznawania jedności życia czynnego i kontemplacyjnego, które mistrz praski wyraźnie i ostro rozróżnia i bynajmniej nie podkreśla, by działanie ludzkie było identyczne z działaniem bożym w duchu aweroistycznego ekartyzmu, a nawet złagodzonego tauleryzmu. J. Wolny, Zagadnienie formacji duchowej królowej Jadwigi (wykład w czasie uroczystości 600-lecia urodzin bł. Królowej Jadwigi w bazylice na Wawelu 17 lutego 1974 r.), ,Notificationes e Curia Metropolitana Cracoviensi" 1974, 63-71. Historia Marii i Marty (Łk 10, 38-42), czytana w dawnej liturgii w dzień dożynkowy 15 sierpnia, stanowiła evangelium laicorum, stale przypominała światu pracy i wladcom ludzkości o wybieraniu „lepszej cząstki” wśród absorbujących zajęć. Urban VI przypomina to w liście do Jagiełły (17 IV 1388): ,in tuae operationis ministerio Marthae sollicitudinem assumas et in altitudinem Mariae contemplationis consurgas", KDWil nr 12, s. 24 . 
parce que ce serait contre la liberté de consense matrimonial. Il était permis de promettre pendant les fiançailles des enfants le paiement de la dot ou du douaire que les parents d'Hedvige et de Wilhelm avaient fixé à 200.000 florins, mais ce n'était qu'une amance conventionnelle.

Hedvige, qui devait être d'abord une princesse autrichienne, ensuite la reine de Hongrie et depuis le Congrès de Sieradz en 1383 fut proclamée reine polonaise, vint en Pologne et fut couronné le jour de sa patronne, le 15 Octobre 1384.

Hedvige séjournait encore en Hongris, quand les magnats polonais se sont reservés les droits que eux seuls devaient choisir son époux, en soulignant par se fait qu'il rejettaient son mariage avec Wilhelm et en commencèrent les pourparlers avec le prince lithuanien Jagiełło pour lui offrir la main de la reine polonaise.

Le 18 Javier 1385 les députés de Jagiełlo sont arrivés à Cracovie en demandant Hedvige comme femme pour leur prince. Mais c'est à cause de la minorité de la jeune reine, la délégation fut renvoyée en Hongrie, chez la reine-mère Elisabeth de Bosnie, qui confirme ce projet et nomme ses représentants pour conclure le contrat de mariage, dont une des conditions était l'annexion de la Lithuanie et de la Ruthénie à la Pologne. La rencontre des députés avec Jagiełło a eu lieu dans une des capitales de Lithuanie, à Krewo le 14 VIII 1385. Dans l'entretemps les Habsbourg ont forcé la reine-mère Elisabeth qui se trouvait dans une situation difficile, pour l'accomplissement du mariage d'Hedvige avec Wilhelm et le 15 Août, c'est à dire le premier jour du sixième mois avant sa majorité selon le principe: „Malitia supplet aetatem”, mais pas plus que 6 mois. C'est dans ce but que Wilhelm est arrivé à Cracovie. Il ne fut pas reçu, mais forcé à quitter la Pologne.. Neuf jours après, les délégués de Krewo sont venus chez Hedvige en lui remettant l'acte qui jusqu'aujourd'hui est conservé dans l'Archive de Chapitre Cathédrale de Cracovie à Wawel. Hedvige se rejouissant d'un arrangement si propice de son mariage (nuptiarum consummatio) a ordonné de mettre en liberté tous les prisonniers de la prison municipaie. Après son arrivée à Cracovie, Jagiello fut baptisé et le 18 Février il épousa Hedvige, qui juste avant cette date a terminé 12 ans et a revuqué et annulé ses ,sponsalia”, contractés par ses parents avec Wilhelm, si, en général, elles étaient pour elle valables, parce qu'après l'âge de 7 ans elle n'a jamais rencontré Wilhelm comme fiancé.

Après le mariage d'Hedvige et de Jagiełło s'est enflammé une violente, mais fausse propagande teutonico-autrichienne, tournée contre le couple royal polonais. Les Autrichiens ont eu le regret de perdre le trône de la Pologne par le renvoi de Wilhelm et les chevaliers teutoniques ont étè déçus que le baptême de Jagiello n'était pas leur oeuvre. En plus, la conversion de la Lithuanie par la Pologne et l'union des deux pays ont créé un état puissant lithuano-ruthéno-polonais, qui a privé l'ordre teutonique de la possibilité des conquêtes suivantes pour augmenter leur territoire. La propagande hostile a formé guatre suivantes thèses fictives:

a) que Wilhelm fut intronisé à Cracovie comme roi de Pologne,

b) que Wilhelm était logé dans le château royal à Cracovie et que son mariage avec Hedvige a èté realisé,

c) que Władysław Jagiello a accepté le baptême d'une façon supperficielle et qu'il est resté au fond un paien; qu'il est arrivé à Cracovie accompagné d'une forte équippe et qu'il a chassé Wilhelm et l'a privé de sa femme qui l'aimait beaucoup et se sentait sa femme,

d) que c'etait le Pape qui a donné son accord pour le concubinat d'Hedvige et de Jagiełło en y donnant sa dispense spéciale.

Ces mystifications ont été proclamées par les chroniques teutoniques autri- 
chiennes, et les HTabsbourg ont adressé à Rome une plainte que les devoirs prises par. Hedvige n'ont pas été gardés et demandaient l'annulation de son mariage ave. Jagiełło.

En défendant la légalité et la sainteté du mariage d'Hedvige avec Jagiełło, la Chaire Apostolique a entrepris quatre actions:

a) en envoyant en 1386 à Vienne le député polonais, Mikołaj Trąba avec une déclaration, que, puisque le mariage de Wilhelm avec Hedvige n'a pas eu lieu, Wilhelim, malgré son mariage arrangé dans son enfance à l'exemple des adultes (le mariage de Hainburg, en 1387), peut, sans aucune difficulté, épouser une autre femme,

b) en envoyant en Pologne son légat Maffioli di Lampugnano qui est arrivé à la cour de Jagiełło en 1386 et a examiné l'affaire sur place; il a informé ensuite tous les princes-électeurs de l'Empire Romain de louable mariage d'Hedvige et de Jagiełło de la sincère conversion du roi et ses mérites pour le développement du christianisme,

c) en renvoyant les prétentions des Habsbourg qui ont perdu le procès déposé à Rome et le Pape a envoyé à Jagiełło une lettre (17 IX 1388) avec des félicitations et des éloges,

d) en acceptant par le Pape Boniface IX la demande d'être le parrain de la fille d'Hedvige et de Jagiełło: Elisabeth-Bonifatia, ce qui prouve, que le Pape a reconnu ce mariage comme légal et sacramental.

Dans le cernier chapitre l'auteur caractérise la spiritualité d'Hedvige comme typiquement franciscaine, traditionnelle déjà chez des reines et princesses à la coúr hongroise et polonaise et en montrant toutes les traits typiques de son caractère, qui sont actuels dans notre temps d'aujourd'hui.

Hedvige a été dans son profil spirituel une personne exeptionnelle, qui peut servir comme modèle et patronne d'un homme moderne. 